\title{
JUSTICIA RESTAURATIVA CON PERSONAS CONDENADAS POR TRIBUNALES EXTRANJEROS TRASLADADAS A ESPAÑA PARA CUMPLIR SU CONDENA
}

"Si existe el infierno, puedo decir que vengo de alli». Preso en Perú durante 6 años y 8 meses.

\author{
Ester Pascual Rodríguez \\ Prof. Contratada Dra. Universidad Francisco de Vitoria \\ Abogada y mediadora \\ Xabier Etxebarria Zarrabeitia \\ Prof. Ayudante Doctor Universidad Complutense de Madrid \\ Abogado ICAM \\ Title: Restorative Justice applied to people convicted by foreign courts and \\ transferred to Spain to serve their sentence
}

Resumen: Suele haber cerca de mil personas españolas encarceladas en multitud de países del mundo. Algunas de ellas solicitan y obtienen el traslado para terminar de cumplir su condena en España. Su historia es una historia de sufrimiento, vejaciones y maltrato y, sin embargo, a su llegada a España deben seguir cumpliendo su condena. El programa «Restauravidas» trata de intervenir desde la justicia restaurativa, pero poco espacio queda para reparar el daño ocasionado cuando el esfuerzo es repararse a sí mismo para sobrevivir.

Palabras clave: Españoles condenados por tribunales extranjeros; Traslado para cumplir condena; Justicia restaurativa; Victimización terciaria; Trato inhumano y degradante dentro de prisión; Violación de derechos humanos; Estándares europeos de derechos humanos y condiciones materiales de las prisiones. 
Abstract: There are usually about a thousand Spanish people imprisoned in many countries around the world. Some of them request and obtain the transfer to finish serving their sentence in Spain. Their story is a story of suffering, systematic humiliation and degrading and inhuman treatment and, nevertheless, upon arrival in Spain they must continue serving their sentence. The "Restauravidas program» tries to intervene with restorative justice aims, but little space remains to repair the damage caused when the effort is to repair oneself in order to survive.

Keywords: Spanish people serving sentences issued by foreign courts; Transfer to serve the sentence; Restorative Justice; Tertiary victimization; Degrading and inhuman treatment inside prisons; Violation of human rights; European human rights standards and prison conditions.

Sumario: 1. Introducción. - 2. «Las mulas». Etiología de su delito y perfilación criminal. - 3. La experiencia en prisión en el extranjero. - 4. La aplicación de la justicia restaurativa a través del programa «Restauravidas». - 5. Bibliografía. - 6. Documentos oficiales e informes. -7 . Sentencias del Tribunal Europeo de Derechos Humanos.

\section{Introducción}

Cuando una persona con nacionalidad española es detenida, juzgada y condenada en el extranjero, puede solicitar, en la mayor parte de los casos $^{1}$, el traslado a su país de nacionalidad ${ }^{2}$, esto es, al objeto de este trabajo, a España.

En este caso hay que distinguir dos supuestos:

1. Que la persona condenada lo haya sido en un país de la Unión Europea. En este caso, la legislación que se aplica para poder solicitar el traslado a España es la Ley 23/2014, de 20 de noviembre, de reconocimiento mutuo de resoluciones penales en la Unión Europea $^{3}$; principalmente en los arts. 63 y ss. Esta Ley posibilita

1 Se excluye, por ejemplo, en el Convenio de Estrasburgo, en caso de que el tiempo de privación de libertad que quede por cumplir sea inferior a 6 meses o que no exista doble incriminación,

2 Conforme al Instrumento de Ratificación del Convenio sobre traslado de personas condenadas, hecho en Estrasburgo el 21 de marzo de 1983 (BOE núm. 138, de 10 de junio de 1985, pp. 17478 a 17481), España declara, al art. 3.4, que «En lo que concierne al presente Convenio, España considerará como nacionales las personas que gocen de esta calidad en virtud de las normas del título I del libro I del Código Civil español.»

En el ámbito de la Unión Europea (véanse arts. 67 y ss. de la Ley 23/2014 y arts. 4 y 6 de la Decisión Marco 2008/909/JAI) no rige esta limitación, aunque la nacionalidad sí es relevante por ejemplo respecto al consentimiento para el traslado (no se exige si es nacional del Estado de ejecución).

3 Que traspone, entre otras, la Decisión Marco 2008/909/JAI, de 27 de noviembre de 2008, relativa a la aplicación del principio de reconocimiento mutuo de sentencias 
que personas condenadas que se encuentren presas en cualquier país de la Unión Europea puedan cumplir la pena o medida de seguridad en España y, a la inversa, que condenados comunitarios que están en territorio español puedan hacerlo en otro país de la Unión Europea. Esta Decisión Marco vino también a modificar el procedimiento existente para solicitar los traslados entre los Estados miembros, fundamentalmente convirtiéndolo en un procedimiento meramente judicial en aplicación del principio de reconocimiento mutuo, consecuentemente con la creación de un espacio único de libertad, justicia y seguridad basado en la confianza entre los Estados Miembros. En nuestro caso el órgano competente para reconocer y acordar la ejecución de las sentencias de países de la UE es el Juzgado Central de lo Penal de la Audiencia Nacional (art. 64.2 Ley 23/20144).

2. Que la persona condenada lo haya sido en un país no miembro de la UE. En este caso, la legislación vigente aplicable es el Convenio sobre traslado de personas condenadas - $\mathrm{n}^{\circ} 112$ - hecho en Estrasburgo el 21 de marzo de $1983^{5}$ o por los convenios bilaterales de ejecución de sentencias penales que España haya suscrito con cada país ${ }^{6}$. En estos casos, la solicitud de traslado ha de ser aprobada por el Ministerio de Justicia del país emisor y por España como país receptor.

Las diferencias entre ambas legislaciones - la Ley de reconocimiento mutuo y el Convenio de Estrasburgo- son importantes. En lo procedimental, en el caso de la Ley de reconocimiento mutuo el procedimiento se desarrolla entre órganos jurisdiccionales de los países afectados, sin necesidad de que entren a formar parte de este las autoridades gubernativas; se trata de un proceso mucho más ágil en el que los plazos se reducen

en materia penal por las que se imponen penas $\mathrm{u}$ otras medidas privativas de libertad a efectos de su ejecución en la Unión Europea.

${ }_{4}$ «La autoridad competente para reconocer y acordar la ejecución de una resolución por la que se impone una pena o medida privativa de libertad será el Juez Central de lo Penal. Para llevar a cabo la ejecución de la misma, será competente el Juez Central de Vigilancia Penitenciaria. Cuando la resolución se refiera a una medida de internamiento en régimen cerrado de un menor la competencia corresponderá al Juez Central de Menores».

5 Para consultar el listado de miembros del Convenio de Estrasburgo hay remitirse a https://www.coe.int/en/web/conventions/full-list/-/conventions/treaty/167/signatures. Este Convenio para el traslado de personas condenadas ha sido firmado por 46 estados miembros del Consejo de Europa, pero también por 22 estados no miembros como Japón, Méjico, Ecuador, Bolivia, EE. UU., Canadá, Venezuela, Israel, India, el Vaticano o Ghana.

6 Para consultar el listado de convenios bilaterales firmados por España hay que remitirse a http://www.exteriores.gob.es/Portal/es/SalaDePrensa/Multimedia/Publicaciones/ Documents/GUIA\%20TRATADOS\%20CON\%20PAISES.PDF. No son firmantes del Convenio de Estrasburgo por ejemplo Argentina, Brasil o Perú, pero estos países sí tienen tratados bilaterales con España, de 29 de octubre de 1987, de 7 de noviembre de 1996 y de 25 de febrero de 1986, respectivamente. 
considerablemente y en el que se no se necesita el consentimiento en todo caso del penado para su tramitación. No intervienen los poderes ejecutivos, y por tanto el criterio político, lo cual se basa en el principio de confianza mutua en el seno de la UE y en el Tratado de Funcionamiento de la UE ${ }^{7}$, desde que el Tratado de Ámsterdam previera la creación de un espacio de libertad, seguridad y justicia en la Unión Europea. En lo sustantivo, en el Convenio de Estrasburgo se excluye la adaptación, o conversión, de la condena, mientras que en el seno de la UE se exige en todo caso la adaptación a la normativa interna.

En ambos casos, cuando llega a España la persona condenada, el órgano encargado de la ejecución de la pena o la medida privativa de libertad penal pertenece a la Audiencia Nacional ${ }^{8}$. A todas ellas se les abre un expediente de ejecución denominado Expediente judicial internacional, en el que se aprueba la liquidación de condena en España, mediante la correspondiente resolución judicial ${ }^{9}$.

Al ser la Sala de lo Penal de la Audiencia Nacional el órgano que entiende de estos Expedientes judiciales internacionales, el órgano competente en materia de vigilancia penitenciaria, entre otras cuestiones para controlar las decisiones de la administración penitenciaria, será el Juzgado Central de Menores de la Audiencia Nacional en funciones de Vigilancia Penitenciaria.

En diciembre del año 2020 había 862 españolas y españoles presos en el extranjero (770 hombres y 92 mujeres ${ }^{10}$ ); en enero de 2019, 950 y en julio de 2018 la cifra llegaba a los 972. Según la Fundación +34, actualmente serían $961^{11}$.

7 Firmado en Roma en 1957 como Tratado constitutivo de la Comunidad Económica Europea, desde entonces ha vivido diversas reformas y denominaciones. Desde la entrada en vigor del Tratado de Lisboa (2009) se conoce como Tratado de Funcionamiento de la UE. La última versión consolidada ha sido publicada en el Diario Oficial de la Unión Europea de 30 de marzo de 2010.

${ }_{8}^{8}$ En virtud del referido art. 64.2 Ley 23/2014 y del art. 65.2 $2^{\circ}$ LOPJ. Las funciones propias de los juzgados de vigilancia penitenciaria serán ejercidas por el Juzgado Central de Menores en funciones de Vigilancia Penitenciaria.

9 En el caso del Convenio de Estrasburgo, España optó por excluir la aplicación de su art. 9.1.b («...convertir la condena, mediante un procedimiento judicial o administrativo, en una decisión de dicho Estado, que sustituya así la sanción impuesta en el Estado de condena para la misma infracción del Estado de cumplimiento para la misma infracción, en las condiciones enunciadas en el artículo 11.»), optando por el 9.1.a («...hacer que prosiga el cumplimiento de la pena inmediatamente o sobre la base de una resolución judicial o administrativa, en las condiciones enunciadas en el artículo 10.»). En el ámbito de la UE, conforme al art. 86 Ley 23/2014, necesariamente «El Juez Central de Vigilancia Penitenciaria deberá ejecutar la resolución condenatoria de acuerdo con lo dispuesto en el ordenamiento jurídico español», procediendo a adaptarla como prevé su art. 83.

${ }_{10}$ Lo cual representa que las mujeres son el 10,67\%; una cifra superior al porcentaje de mujeres encarceladas respecto al total en España, que se sitúa en el 7,6\%. En Europa, el 4,9\%.

11 Fundación que debe su nombre el prefijo telefónico de España (http://www.fundacionmas34.org, última consulta 30 de mayo de 2021). 
En la siguiente tabla se observan los cinco países de la UE con mayor número de personas presas de nacionalidad española a diciembre de 2020:

\begin{tabular}{|c|l|c|c|c|}
\hline \multicolumn{5}{|c|}{5 Países europeos con más presos españoles } \\
\hline Clasificación & \multicolumn{1}{|c|}{ País } & $\begin{array}{c}\text { Números de presos } \\
\text { españoles }\end{array}$ & $\begin{array}{c}\text { Delito } \\
\text { Drogas }\end{array}$ & $\begin{array}{c}\text { Sexo } \\
\text { Masculino }\end{array}$ \\
\hline 1 & Francia & 145 & 83 & 136 \\
\hline 2 & Alemania & 113 & 36 & 104 \\
\hline 3 & Portugal & 45 & 29 & 39 \\
\hline 4 & Reino Unido & 32 & 14 & 30 \\
\hline 5 & Bélgica & 38 & 13 & 35 \\
\hline & Total & $\mathbf{3 7 3}$ & $\mathbf{1 7 5}$ & $\mathbf{3 4 4}$ \\
\cline { 2 - 5 } & & & $47 \%$ & $73 \%$ \\
\hline
\end{tabular}

En la siguiente tabla podemos ver los cinco países del mundo no europeos con mayor número de presos españoles en diciembre del año $2020^{12}$ :

\begin{tabular}{|c|l|c|c|c|}
\hline \multicolumn{5}{|c|}{5 Países europeos con más presos españoles } \\
\hline Clasificación & \multicolumn{1}{|c|}{ País } & $\begin{array}{c}\text { Números de presos } \\
\text { españoles }\end{array}$ & $\begin{array}{c}\text { Delito } \\
\text { Drogas }\end{array}$ & $\begin{array}{c}\text { Sexo } \\
\text { Masculino }\end{array}$ \\
\hline 1 & Marruecos & 98 & 74 & 93 \\
\hline 2 & Perú & 46 & 44 & 37 \\
\hline 3 & $\begin{array}{l}\text { Estados } \\
\text { Unidos }\end{array}$ & 32 & 7 & 31 \\
\hline 4 & Colombia & 22 & 21 & 18 \\
\hline 5 & Brasil & 16 & 10 & 12 \\
\hline & Total & $\mathbf{2 1 4}$ & $\mathbf{1 5 6}$ & $\mathbf{1 9 1}$ \\
\cline { 2 - 5 } & & & $73 \%$ & $89 \%$ \\
\hline
\end{tabular}

Durante el año 2020, con motivo de la pandemia de la Covid-19, los traslados, que realiza Interpol, fueron interrumpidos en el mes de marzo, siendo reanudados lentamente conforme las circunstancias

12 Datos obtenidos de la Dirección General de españoles en el Exterior y Asuntos Consulares a través del Informe anual de Apoyo a las personas españolas presas en el extranjero de diciembre de 2020 realizado por la Fundación Abogacía Española. 
lo fueron permitiendo. En España, las mujeres y hombres españoles trasladados desde el extranjero son enviados en un primer momento al centro penitenciario de Madrid V (Soto del real), a excepción de quienes son trasladados desde Marruecos, que son enviados al Centro Penitenciario de Botafuegos en Cádiz. Posteriormente tendrán la opción de ser nuevamente trasladados a centros penitenciarios más cercanos a sus lugares de reinserción, donde tienen algún tipo de arraigo, tal y como sucede, o debería suceder ${ }^{13}$, con el resto de la población reclusa española.

Analizando los datos que se ofrecen en las dos tablas anteriores, se observa que la causa principal de encarcelamiento de españoles en el extranjero se debe a la comisión de delitos de tráfico de drogas, puesto que el $73 \%$ de las personas que se encuentran presas en los cinco países no europeos con mayor número de presos españoles lo está por delitos contra la salud pública y el $47 \%$ de los presos que se encuentran en los cinco países de la Unión Europea con mayor número de presos españoles también lo está por esa tipología delictiva.

El informe mundial sobre drogas de 2020 de la Oficina de las Naciones Unidas contra la Droga y el Delito ${ }^{14}$ concluye que el consumo global ha aumentado, a pesar del alto impacto que ha tenido la COVID-19 en los mercados mundiales de drogas. Si bien es cierto que actualmente se desconoce el impacto de la pandemia en el mercado de las drogas, es probable que sea de gran alcance. Teniendo en cuenta las consecuencias derivadas de la crisis económica de 2008, con el aumento del desempleo y la falta de oportunidades, será más probable que las personas pobres y desfavorecidas caigan en hábitos nocivos de consumo de drogas, sufran como consecuencia trastornos y recurran a actividades ilegales — bien de producción, bien de transporte- vinculadas a las drogas. También es muy previsible que las organizaciones que se dedican al tráfico de drogas se aprovechen de esta situación engrosando sus filas con nuevos miembros. Como dice el referido Informe, «Los más desfavorecidos sufren los daños de los mercados de drogas legales e ilegales» ${ }^{15}$.

13 Según los datos obtenidos del estudio de preguntas hechas por el Senado al Gobierno de 2017, los datos proporcionados por la SGIIPP indican, por los porcentajes que arrojan, que el cumplimiento en centro penitenciario fuera de la comunidad autónoma de residencia está lejos de ser una excepción. Los porcentajes se sitúan desde el $66 \%$ de personas en un centro penitenciario fuera de la comunidad autónoma de residencia en el caso de Castilla La Mancha, 55\% en Ceuta y Melilla o 51\% en el caso de Euskadi, hasta el 9\% en el caso de Madrid: un 26\% en el caso de Canarias, $25 \%$ en el de Galicia, $32 \%$ el de Andalucía, 33\% en el de Cantabria, 35\% el de La Rioja, 40\% en el de Castilla y León, 30\% el de Murcia, $48 \%$ el de Valencia.

14 UNODC, World Drug Report 2020. https://wdr.unodc.org/wdr2020/index.html.

15 Ibidem, p. 15. 
A pesar de las campañas de concienciación ${ }^{16}$ sobre los riesgos que conlleva la comisión de un delito de tráfico de drogas en el extranjero y las altísimas y durísimas condenas a las que puede dar lugar ${ }^{17}$, se siguen produciendo detenciones y condenas de españoles fuera de nuestras fronteras ${ }^{18}$. ¿Cuál es el motivo por el que se arriesgan?, ¿conocen las personas condenadas el alcance e impacto de una detención, ingreso en prisión, juicio y condena por este tipo de delitos en sus vidas?, ¿a qué dificultades deben enfrentarse en el cumplimiento de la pena de prisión en los países extranjeros?, ¿puede la justicia restaurativa hacerse un hueco en el trabajo con personas condenadas por este tipo de delito y alcanzar sus fines propios?

La justicia restaurativa gira en torno a tres ejes: $1^{\circ}$ ) la reparación, material y/o emocional, a la víctima del delito; $2^{\circ}$ ) la responsabilización por la conducta infractora por parte del victimario a través de la comprensión del impacto del delito con la finalidad de que no vuelva a reincidir y $3^{\circ}$ ) la pacificación social, a través de la regeneración de la confianza de la sociedad en este tipo de justicia y de su alcance positivo en la prevención de futuras acciones delictivas ${ }^{19}$. Desde este punto de partida se planteó la necesidad de estudiar su viabilidad y eficacia ante esta tipología delictiva y con el perfil de personas que veremos más adelante.

Se intentará dar respuesta a esta cuestión a través de los datos y de la experiencia obtenidos en el Programa Restauravidas: reintegración al

${ }^{16}$ El Ministerio de Sanidad tiene planes anuales contra el consumo y el tráfico de drogas y todos los años se realizan campañas de prevención. Por ejemplo, el Plan Nacional contra la Droga con la Fundación Ramón Rubial (https://www.astursalud.es/documents/31867/226271/Infosan.pdf/c0d914b9-6e97-a326-340f-02ae9f2016b7); la realizada con el Movimiento por la Paz en 2016 (https://pnsd.sanidad.gob.es/noticiasEventos/campannasPreventivasInformativas/otrasCampannas/pdf/cartel-MPDL-2016.pdf) o la más reciente en 2019 (https://www.mpdl.org/noticias/espana/sensibilizacion-movilizacion/ campana-viajar-drogas-detiene-tu-vida\#sthash.3Ktj36uD.SuOCts53.dpbs).

A su vez, existe un día mundial específico contra la droga-26 de junio-. También recientemente se ha elaborado un cortometraje que narra con voces reales la experiencia de encarcelamiento por trasladar droga, titulado "Mula», que ha sido galardonado con el premio al mejor corto internacional en el Festival Latino de Cine de Miami de 2020. Dicho cortometraje puede visionarse en http://www.sermula.com.

17 La serie documental de La Sexta «Encarcelados» (https://www.lasexta.com/programas/encarcelados, última consulta 30 de mayo de 2021) tuvo un altísimo impacto en la opinión pública, además de que son numerosos los documentales sobre las durísimas condiciones penitenciarias en las cárceles latinoamericanas, sin que ello parezca surtir efecto preventivo-general.

18 Podemos decir que la «radiografía general» que en mayor medida prevalece es una situación de desesperación; una desesperación mucho mayor que el miedo a ser detenidos, juzgados y condenados, pues en esa ignorancia de la mecánica comisiva «uno nunca piensa que le van a coger», "si otros, que yo he conocido, lo han hecho y no les han pillado, a mí tampoco».

19 Véase al respecto la básica obra de H. ZEHR, El pequeño libro de la justicia restaurati$v a$, Good books, 2005, en la que desarrolla magistralmente estos tres pilares de la justicia restaurativa 
lugar de origen, impulsado por la Fundación Abogacía Española ${ }^{20}$, que tiene entre sus objetivos prioritarios apoyar las solicitudes de traslado de españoles en el extranjero para que puedan venir a terminar de cumplir sus condenas a sus lugares de origen, esto es, a centros penitenciarios de nuestro territorio nacional.

En 2018 había 970 personas de nacionalidad española en cárceles extranjeras. Entre enero y octubre de 2018 llegaron 87 personas trasladadas a España para continuar con el cumplimiento de sus condenas, lo que significa que de media son trasladadas 4 o 5 al mes. Por su trabajo en apoyo a los españoles encarcelados en el extranjero, se detectó por parte de la Fundación Abogacía la necesidad de reforzar la acogida en España a través de un acompañamiento jurídico y psicológico temprano, nada más llegar a España, a Soto del Real, que es la primera prisión en la que ingresan, que les procurase información y herramientas para hacer frente a su nueva situación. Desde ahí surgió la idea de incorporar en el ámbito penitenciario un programa específico para estas personas basado en los principios y fines que promueve la justicia restaurativa, con la finalidad de comprobar su utilidad y viabilidad. Este proyecto entre la Secretaría General de Instituciones Penitenciarias y la Fundación Abogacía ha recibido la denominación de «Restauravidas: reintegración al lugar de origen». Desde su comienzo el 4 de octubre de 2019 hasta el 30 de marzo de 2021 han participado, de manera voluntaria, 23 personas, de las cuales, 21 entran en el estudio que se realiza en este artículo, por tratarse de personas condenadas por delitos contra la salud pública.

\section{2. «Las mulas». Etiología de su delito y perfilación criminal}

Como ya hemos visto en la introducción, la mayoría de las personas de nacionalidad española que están en prisiones extranjeras -bien en situación de prisión preventiva, bien cumpliendo la pena- lo están por la comisión de delitos contra la salud pública - tráfico de drogas-, concretamente el $74 \%{ }^{21}$. De estas, el $90 \%$ están condenadas por «haber

20 Dicho programa -impulsado por Macarena Eseverri, Kiko Segovia y Elisa Marraco, de la Fundación Abogacía Española-, se ha llevado a cabo entre dos profesionales expertas en prácticas restaurativas, y psicología en el caso de Francisca Lozano Espina, y derecho penitenciario en el caso de Esther Pascual. Han participado en dicho programa desde el inicio el 4 de octubre de 2019, hasta el mes de abril de 2021, 24 personas españolas trasladadas desde países extranjeros. Con el fin de estudiar el impacto del programa en las personas presas y dar difusión al mismo se ha realizado un proyecto de investigación a cargo de la Universidad Francisco de Vitoria.

${ }^{21}$ El tráfico de drogas sería el delito más cometido en Europa, el 18\% de total en 2020, según los datos del Informe SPACE (Statistiques Pénales Annuelles du Conseil de l'Europe) en 2012, 2013, 2014, 2018, 2019 y 2020. Véase AeBI, M. F., y Tiago, M. M.,

(C) UNED. Revista de Derecho Penal y Criminología, 3. ${ }^{a}$ Época, n. ${ }^{\circ} 26$ (2021) 
hecho de mulas». Según el Observatorio Europeo sobre las Drogas y la Toxicomanía (OEDT) se entiende por «mula de drogas» a la «persona que actúa como correo de drogas a quien se le paga, se le coacciona o se le engaña, para transportar drogas a través una frontera internacional, pero que carece de mayor interés comercial en las drogas en cuestión». A su vez, el mismo Observatorio distingue dos tipos de correos de drogas: el autónomo o «la mula». Los correos autónomos organizan la importación y venta de drogas por su cuenta, por lo que obtienen un mayor beneficio, mientras que las «mulas» se limitan a transportar las drogas a cambio de un pago predeterminado. Parece, por lo tanto, que el factor clave para determinar si un correo es una «mula» es hasta qué punto esa persona organiza la importación de drogas y obtiene el «beneficio comercial» con ella ${ }^{22}$.

Mucho se ha escrito a nivel nacional ${ }^{23}$ e internacional ${ }^{24}$ sobre la proporcionalidad de las penas en los delitos contra la salud pública, fundamentalmente en lo relativo a las penas impuestas a las «mulas», precisamente por darse en la persona infractora las siguientes circunstancias: pobreza, precariedad, angustia económica y en la mayor parte de los casos, un sufrimiento humano al que el derecho debería atender y dar respuesta. En nuestro país la LO 5/2010, de 22 de junio, rebajó la pena del tipo básico de nuestro código penal $-\mathrm{y}$

SPACE I -2020- Council of Europe Annual Penal Statistics: Prison populations. Strasbourg: Council of Europe. 2021, https://wp.unil.ch/space/space-i/annual-reports.

Es muy llamativa la prevalencia de este delito entre las mujeres encarceladas en España. En 20191.085 de las 3.803 mujeres presas en España lo estaban por tráfico de drogas (28,53\%), en evolución descendente de la última década (en 2012 fueron 2.275 de 4.519, esto es, el 50,34\%), según datos de los Informes generales de Instituciones Penitenciarias, accesibles en http://www.interior.gob.es/web/archivos-y-documentacion/documentaciony-publicaciones/publicaciones-descargables/publicaciones-periodicas-anuarios-y-revistas-/informe-general-de-instituciones-penitenciarias, el Informe de 2021 de la Secretaría General de Instituciones Penitenciarias, La situación de la mujer privada de libertad en la Institución Penitenciaria, así como el Informe sobre la situación de las mujeres presas. Tratamiento y derechos de las mujeres privadas de libertad en los centros penitenciarios de España y Andalucía de la APDHA de 2020. Con gran conocimiento experiencial, M. Aguilera ReIJA, "Mujeres en prisiones españolas», La cárcel del siglo XXI: desmontando mitos y recreando alternativas, Año 61, $\mathrm{n}^{\circ} 973,2011$, p. 44-48.

22 A definition of "drug mules» for use in a European context. European Monitoring. Centre for Drugs and Drug Addiction. Lisboa, 2012, p. 3.

${ }^{23}$ Por destacar alguna obra y dado que resume muy bien la opinión de la doctrina mayoritaria nos remitimos a M. MARTínez EscamilLa, «Pobreza, estado de necesidad y prevención general: los correos de la cocaína y el tribunal supremo español», Derecho Penal Contemporáneo: Revista Internacional, $\mathrm{n}^{\circ} 12$, 2005. Más antigua sería la de E. MoNTESERín, Los correos de la cocaína. Tesis doctoral. Universidad Complutense de Madrid. 1995. Más recientemente, C. Molina BlázQuez, «Necesidad y derecho penal: el hurto famélico, los "correos de la coca" y la ocupación pacífica de inmuebles", en BENITO SÁNCHEZ y Gómez Lanz (dirs.), Sistema penal y exclusión social, Cizur Menor, Aranzadi, 2020, pp. 109-138.

${ }^{24}$ Con el mismo propósito véase G. LAI, «Drogas, crimen y castigo. Proporcionalidad de las penas por delitos de drogas» en la Serie reforma legislativa en materia de drogas, $\mathrm{n}^{\circ} 20$, Transnational Institute, junio 2012. 
consecuentemente del tipo agravado- en sustancias que causan grave daño a la salud, además de introducir el subtipo atenuado del párrafo segundo del art. $368 \mathrm{CP}^{25}$. Esto ha supuesto para las «mulas» ${ }^{26}$, conforme a nuestra legislación, la reducción del límite mínimo de la pena privativa de libertad de 9 años y 1 día a 6 años y 1 día por ejemplo en supuestos de notoria importancia (art. 369.1 CP: pena superior en grado a las del art. 368), que en estos casos será lo más frecuente (en general por superar los 750 gramos de cocaína $\left.{ }^{27}\right)^{28}$. También en otras legislaciones de Europa y del sur y centro de América en atención al principio de proporcionalidad se han revisado las sanciones y no se aplica la pena en su grado máximo para este perfil de infractores ${ }^{29}$. Sin embargo, que no se les imponga la pena máxima no significa que

25 Se modificó el artículo 368, que quedó redactado como sigue:

«Los que ejecuten actos de cultivo, elaboración o tráfico, o de otro modo promuevan, favorezcan o faciliten el consumo ilegal de drogas tóxicas, estupefacientes o sustancias psicotrópicas, o las posean con aquellos fines, serán castigados con las penas de prisión de tres a seis años y multa del tanto al triplo del valor de la droga objeto del delito si se tratare de sustancias o productos que causen grave daño a la salud, y de prisión de uno a tres años y multa del tanto al duplo en los demás casos.

No obstante lo dispuesto en el párrafo anterior, los tribunales podrán imponer la pena inferior en grado a las señaladas en atención a la escasa entidad del hecho y a las circunstancias personales del culpable. No se podrá hacer uso de esta facultad si concurriere alguna de las circunstancias a que se hace referencia en los artículos 369 bis y 370.»

Como indica el preámbulo de la LO, esta modificación se basa en el Acuerdo del Pleno No Jurisdiccional del TS Sala $2^{\text {a }}$ de 25 de octubre de 2005: "Cuando se trate de cantidades módicas las penas deberían ser de seis meses a dos años de prisión cuando se trate de sustancias que no causen grave daño a la salud, y de dos a cinco años si se trata de sustancias que sí causan grave daño a la salud». Igualmente se aprueba como propuesta alternativa a la anterior el añadir un segundo párrafo al actual art. $368 \mathrm{CP}$. con el siguiente texto: «No obstante lo dispuesto en el párrafo anterior, los Tribunales podrán imponer la pena inferior en grado atendiendo a la gravedad del hecho y a las circunstancias personales del culpable».

Véase sobre la génesis y fundamentación del precepto X. ETXEBARRIa ZarRabeitia, «Propuesta de interpretación del segundo párrafo del art. 368 del Código penal», La Ley Penal, n ${ }^{\circ} 85$, Sección Legislación aplicada a la práctica, septiembre 2011, pp. 3-11.

26 Concepto diferente del de «boleros». En estos casos, las personas llevan dentro de su organismo la cocaína embalada, pues la introducen por la boca poco antes de realizar el viaje con la idea de expulsarla del organismo en el país de destino. Esta práctica es muy peligrosa y puede acarrear la muerte de la persona que ha ingerido las bolas de cocaína. Aquí un grave riesgo para la salud muy serio.

27 Acuerdo del Pleno de la Sala 2a del Tribunal Supremo de 19 de noviembre del 2001.

28 Dada la gran prevalencia de este delito entra las personas encarceladas en España, esta modificación legal ha sido una de las principales causas de la reducción de la población penitenciaria en España desde 2010. Véase un análisis de la incidencia de esta reforma en J. CID MoLINÉ, «El futuro de la prisión en España», Revista Española de Investigación Criminológica, art. 1, n. 18, 2020, pp 1-32.

${ }_{29}$ Véase al efecto los Códigos Penales de Perú, Brasil, Argentina, Bolivia, etc. Véase el caso de Ecuador, cuando en agosto de 2014 fue aprobado en Ecuador el nuevo Código Orgánico Integral Penal, en el documento de la Fundación Abogacía Informe-final.pdf (abogacia.es), última consulta 30 de mayo de 2021. 
sus conductas queden impunes o que se les imponga la pena mínima. De media suelen imponerse en los referidos países latinoamericanos entre 6 y 7 años cuando se trata de «mulas» ${ }^{30}$.

La eximente de estado de necesidad o atenuante muy cualificada no se suele aplicar, ni por los tribunales españoles, ni por los tribunales extranjeros ${ }^{31}$. Es muy difícil demostrar en un proceso penal la necesidad imperiosa de conseguir "un dinero rápido» y los tribunales siempre consideran que hay muchas otras opciones antes de recurrir a este tipo de delito para salvar esa situación de dificultad económica ${ }^{32}$. Además, hay que tener en cuenta que cuando las personas que hacen de «mulas» son detenidas en muchas ocasiones lo son en un país extranjero - bien españoles que han salido de nuestras fronteras para introducir droga que son detenidas al intentar subir al avión del país desde donde la van a portar; o bien personas extranjeras que son detenidas al llegar al aeropuerto de Barajas y que portan una maleta o mochila con cocaína-. En estos casos, la persona es detenida y procesada en un país extranjero, sin medios económicos, por lo que probar cualquier circunstancia siempre es muy complicado. A esto hay que añadir que muchas de las personas que hacen de mulas y son detenidas han mentido a sus familias sobre el motivo de su viaje y por lo tanto no quieren que se comunique a sus familias el hecho de la detención, ni el motivo, lo que implica no poder pedir documentación a efectos probatorios. En muchos de los casos, informan a las familias cuando ya son condenadas y por lo tanto no pueden solicitar la aplicación de una circunstancia modificativa de la responsabilidad criminal.

La ruina económica y un futuro incierto sin perspectivas de ninguna clase son características que comparten las personas españolas que deciden viajar fuera de nuestras fronteras para hacer de «mulas», intentando introducir desde un país extranjero a España cocaína a cambio de obtener una cantidad económica. De los participantes en el programa Restauravidas, el 91\% están cumpliendo condena por la comisión de un delito contra la salud pública y el $87 \%$ lo están por haber ejercido de «mulas».

Los datos estadísticos de las 24 personas participantes en el programa Restauravidas reflejan lo que se indica en los siguientes párrafos y gráficos.

30 En Perú es sobradamente conocido el denominado «6 con 8», para referirse a la pena de 6 años y 8 meses de prisión que suelen imponer a las «mulas» que intentan venir a España con cocaína.

31 Martínez Escamilla, op. cit., p. 36; Molina Blázquez, op. cit., p. 128.

32 Véase, desde la STS Sala $2^{\mathrm{a}}$ 667/1996, de 8 de octubre, ECLI:ES:TS:1996:5367 hasta la STS Sala $2^{\text {a }} 238 / 2018$, de 22 de mayo, ECLI:ES:TS:2018:1905. In extenso en la tesis doctoral A.L. CALle CALDERón, El estado de necesidad y el caso de las drogas en la doctrina del Tribunal Supremo. Una crítica desde la perspectiva latinoamericana. Tesis doctoral. Universidad de Girona. 2015. 


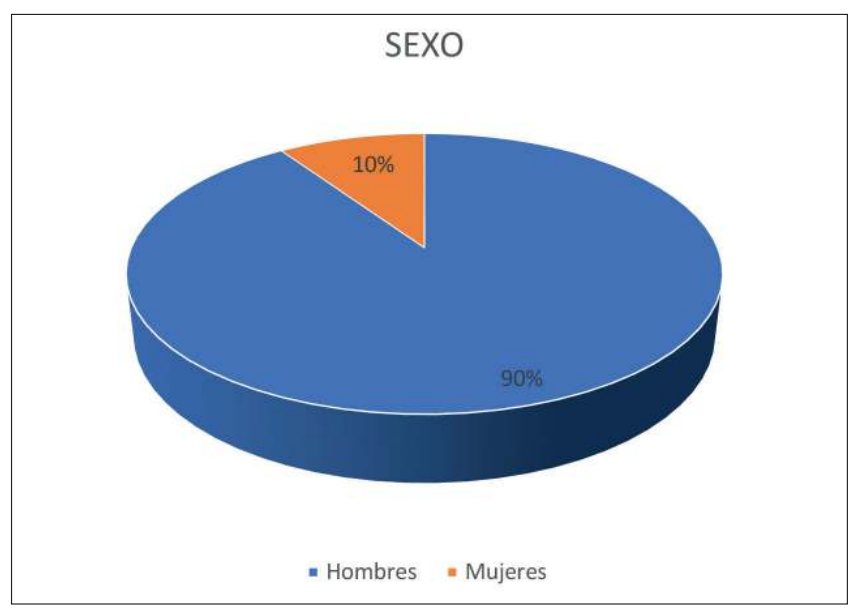

Al igual que sucede en nuestra realidad penitenciaria - las cárceles españolas albergan actualmente a 4.518 mujeres presas, que representan un $7,6 \%$ de la población reclusa total ${ }^{33}$ - el número de encarcelados por ejercer de «mulas» de sexo masculino prevalece sobre el sexo femenino de manera muy significativa, pero en un porcentaje inferior al que se da en la población encarcelada en España y aún más respecto a Europa. Como vemos, el 90\% de las personas españolas condenadas en el extranjero por tráfico de drogas que ha sido trasladada a España para terminar de cumplir sus condenas son hombres, frente a $10 \%$ de mujeres.

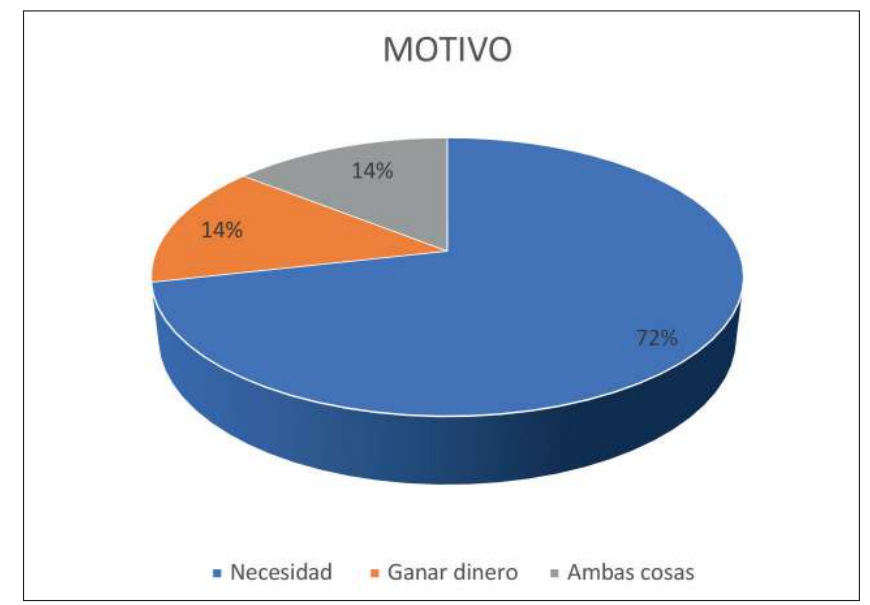

33 Récord de encarcelamiento femenino en Europa occidental, donde el porcentaje es del 4,5\%, según las estadísticas de la Secretaría General de Instituciones Penitenciarias (https://www.institucionpenitenciaria.es/es/web/home/estad\%C3\%ADstica-mensual). 
Como se desprende de este gráfico, de elaboración propia, la motivación al delito en la mayor parte de los casos es la vivencia de necesidad económica. Los participantes recordaban con total nitidez encontrarse en una situación de desesperación real.

En el apartado que lleva por rúbrica «necesidad» se encuentran personas que describen situaciones extremas como vivir en la calle; no encontrar trabajo a pesar de buscar incesantemente durante años; el embargo del inmueble y la posterior ruina de los avalistas - los padres-, el desalojo de la vivienda por no pagar el alquiler durante meses con hijos menores a cargo, etc. Todas las vivencias narradas constituían auténticos dramas vitales y los protagonistas de estas, vieron en esta opción la mejor solución, la única.

La crisis económica ${ }^{34}$ del 2008 al 2014 generó en nuestro país situaciones de precariedad absoluta. Como se desprende de los relatos de las personas participantes en el programa, muchos jóvenes tuvieron que entregar sus viviendas hipotecadas al banco y seguir pagando la deuda $\mathrm{y}$ volver a casa de sus padres, que a su vez como avalistas de sus hijos también estaban perdiendo las viviendas, debiendo repartirse entre casas de familiares y amigos. Otros, cercanos a los cincuenta años, veían como su situación de paro de larga duración solo los llevó a una depresión profunda que paliaron a través del alcohol, y que les generó en algunos casos el rechazo de su familia, encontrándose por tanto y literalmente en la calle. Otros sufrieron un desalojo por no poder pagar el dinero del alquiler y tuvieron que ser acogidos en asociaciones y ONG. Otros no pudieron encender la calefacción durante años y enfermaron o vieron enfermar a sus mayores. Otros no dejaron de visitar el banco de alimentos de su parroquia.

Por lo tanto, cuando nos referimos a verdadera necesidad, lo hacemos atendiendo al tenor literal de la palabra, para poder hacer frente a lo más básico: techo y comida; y no en términos de querer mejorar sus cuentas u obtener caprichos por la vía rápida.

En la rúbrica «ganar dinero» quedan representados los que lo hacen meramente por obtener dinero rápido y en cantidades importantes; personas que trabajan para mafias convencidas de lo que hacen y a las que les compensa hacerlo por el dinero que obtienen. Estas personas no lo hacen por necesidad. Como vemos, representan al 14\% de las personas trasladas para cumplir condena en España que han participado en el programa Restauravidas.

34 En menos de 30 años, España ha vivido tres crisis económicas. La del 1993-1995, la del 2008-2014 y la actual. Cada una ha superado en intensidad a la anterior, según el Instituto Nacional de Estadística. 
La última rúbrica engloba a los que lo hacen por ambos motivos, la necesidad económica y ganar dinero. Estas personas comenzaron a hacer de «mulas» por estricta necesidad y dado el éxito de sus viajes y una vez superado el miedo a la comisión del delito y la situación económica acuciante, repiten, dada la importante suma de dinero que obtienen en cada viaje de manera rápida y sencilla.

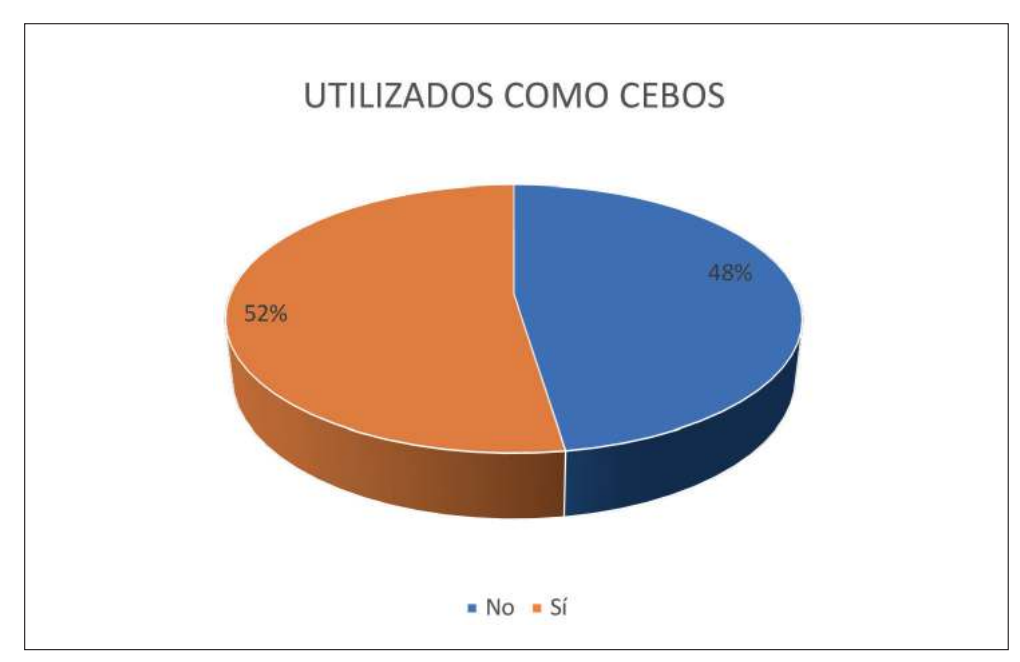

Los «cebos» son personas que hacen de «mulas» y que son utilizadas por las mafias para «entretener» de manera intencionada a la policía de aduanas mientras les registran a ellos y a sus pertenencias, encontrando lógicamente la cocaína que iban a trasladar desde otra parte del mundo a España. Mientras la policía está «entretenida» con estas personas y sus pertenencias, las mafias cuentan con otras personas que logran llegar hasta el avión obviando esos controles. Los «cebos» van totalmente engañados y sólo se percatan de que lo son cuando son detenidos y descubren que la persona que contactó con ellos ya no existe, así como tampoco el teléfono que les proporcionó. Ahí se percatan de que han sido engañadas y utilizadas, lo cual intensifica su rabia, su enfado y su ira. Como podemos ver en el gráfico, el $52 \%$ de las 24 personas que hicieron de mulas fueron utilizadas como cebos. Es decir, más de la mitad son engañadas. Las mafias les hacen creer que van a realizar el viaje de manera segura, cuando los están entregando de manera intencionada para poder pasar mayores cantidades y obtener así más beneficio. Son un coste de explotación. 


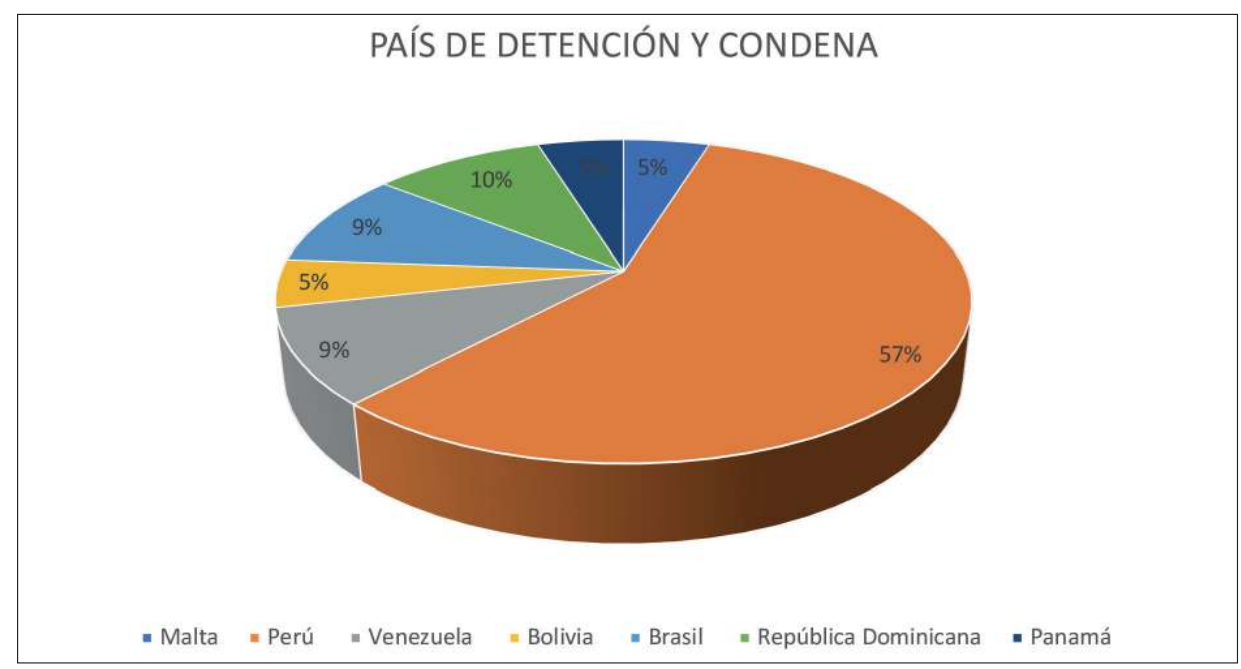

Este gráfico arroja dos datos muy evidentes: el primero, que el país donde hay más españoles detenidos, juzgados y condenados por hacer de «mulas» es Perú ${ }^{35}$; y el segundo, que a su vez Perú, es el país que más personas presas traslada a nuestro territorio nacional. Esto se debe por un lado a los acuerdos bilaterales entre ambos países ${ }^{36}$ y las relaciones consulares y en segundo lugar a una mejora de la asistencia letrada a los presos españoles en Perú a la hora de tramitar las solicitudes de traslado ${ }^{37}$. Le sigue República Dominicana y después Venezuela y Brasil.

La mayor parte de las personas encarceladas había cometido su primer y único delito, frente al 29\% que ya había sido juzgadas y condenadas con anterioridad por el mismo tipo de delito o por otro.

Esto significa que su primera y única vivencia respecto a la detención, enjuiciamiento y estancia en prisión la han tenido en un país extranjero (de los antes expuestos), sin haber tenido relación previa con

35 También en años anteriores. Véase Defensor del Pueblo, Estudio sobre La situación de los presos españoles en el extranjero, Madrid, 2015, p. 12.

36 Como se indicaba al comienzo, Perú no es firmante del Convenio de Estrasburgo, pero existe una relación bilateral basada en el Tratado entre el Reino de España y la República del Perú sobre transferencia de personas sentenciadas a penas privativas de libertad y medidas de seguridad privativas de libertad, así como de menores bajo tratamiento especial, hecho en Lima el 25 de febrero de 1986 (BOE 186, de 5 de agosto de 1987) y el Tratado de Extradición entre el Reino de España y la República del Perú, hecho en Madrid el 28 de junio de 1989 (BOE 21, de 25 de enero de 1994; modificado por Canje de Notas de 9 de marzo de 2009).

37 La Fundación Abogacía Española cuenta en Perú con una letrada especializada en estos asuntos que ha incentivado los traslados. 


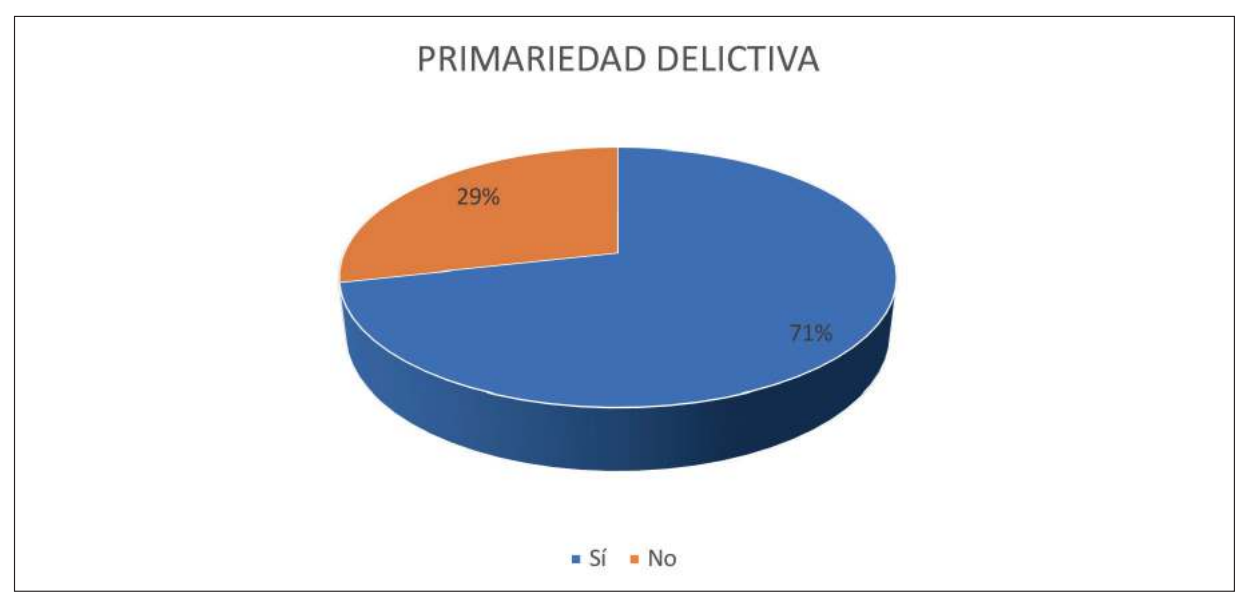

el sistema penal, menos aún con el penitenciario. En sus narraciones - excepto en Malta - coinciden en que en el momento de la detención se sintieron tremendamente indefensos, sin una adecuada defensa letrada al detenido, ni una correcta información de los derechos que les asistían, así como un desamparo total de los consulados españoles. Relatan que la corrupción es sistémica y sistemática y la violencia física y verbal está muy presente en las actuaciones policiales. Narran que quien tiene muchas posibilidades económicas puede costearse una buena defensa letrada y conseguir una sentencia de conformidad condenatoria de corta duración. Quien no goce de ese raro privilegio bien puede prepararse para vivir un auténtico infierno.

\section{EDADES DE LAS PERSONAS CONDENADAS}

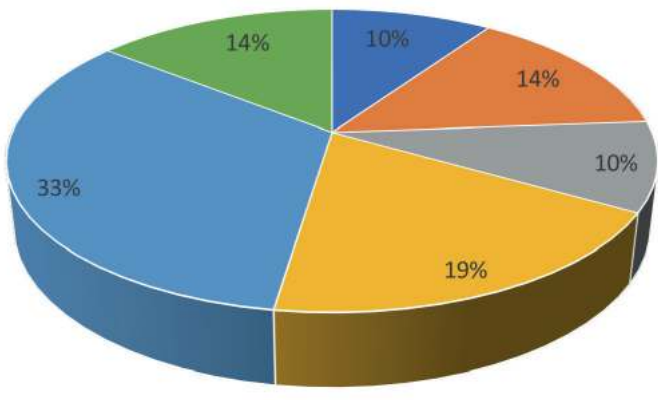

- De 30 a 35 años = De 36 a 40 años - De 41 a 45 años

- De 46 a 50 años |- De 51 a 55 años = De 56 a 60 años 
En el gráfico no se muestra la franja de edad inferior a los 30 años porque no hay condenados españoles por hacer de «mulas» en esa franja de edad. Esto no significa que no haya jóvenes menores de 30 años trasladando droga de un lugar a otro. Quizás lo hagan en otras zonas y por otros medios. Los datos del gráfico ponen de relieve que los menores de 30 años no viajan en avión con droga haciendo de «mulas» desde el sur y centro del continente americano. Por su edad, no reúnen el perfil para entrar a ejercer de «mulas» todavía.

El rango de edad más numeroso que comete este tipo de delito entre las 24 personas participantes en el programa lo encontramos en la franja de los 51 a 55 años, seguida de la de 46 a 50 años.

La franja de edad menos significativa es precisamente la de las personas más jóvenes, esto es, de 30 a 35 años y de 41 a 45 años. Hay una explicación para que la franja de entre 30 y 35 años sea de las menos numerosas. Sucede que muchos de los jóvenes de esas edades todavía no han tenido tiempo de "arruinarse» de tal forma que no encuentren otra salida.

\section{TIEMPO DE ESTANCIA EN PRISIÓN EN EL EXTRANJERO}

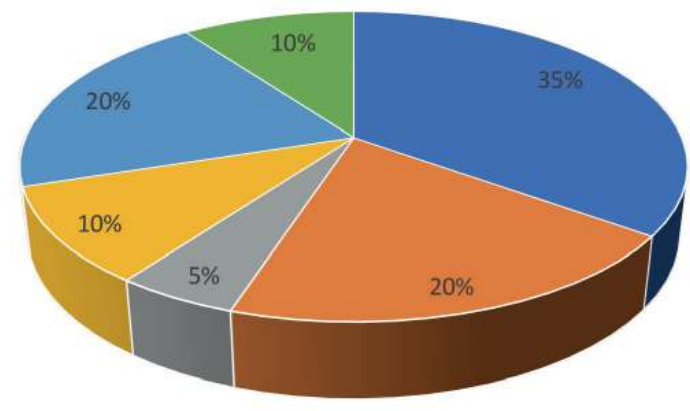

- Menos de 2 años = Menos de 3 años - Menos de 4 años

- Menos de 5 años = Menos 7 años - Más de 10 años

El período medio de estancia en el extranjero hasta que se produce el traslado a España en los 24 casos del programa es de hasta 2 años en el 35\% de los casos y hasta los 3 años en el 20\%, coincidiendo este porcentaje con el de personas que son trasladadas cuando llevan casi 7 años. La totalidad de las personas que han sido trasladadas cuando llevaban 
casi 7 años lo han hecho "desde la calle» ${ }^{38}$, con el certificado de liber$\operatorname{tad}^{39}$, puesto que se han licenciado definitivamente en el país de condena, en este caso Perú, toda vez, que allí suele imponerse el denominado «6 con 8» antes referido. En estos casos, ya no se aplica la legislación en materia de traslados, sino que se realiza la repatriación por motivos humanitarios, ayuda económica consular de carácter reintegrable, siendo acordada por el Ministerio de Asuntos Exteriores, Unión Europea y Cooperación en virtud de los requerimientos que efectúan los consulados de España en el extranjero ${ }^{40}$.

Desde la detención hasta la celebración del juicio — suelen ser juicios donde hay conformidad-suelen transcurrir de media unos 6 meses. Y a partir de ahí y una vez condenados pueden solicitar al traslado para cumplir en España. Este trámite lleva a su vez años, dependiendo del país y del momento coyuntural en el que ambos (país de condena y España) se encuentren. Por ejemplo, con motivo de la pandemia se han paralizado numerosos vuelos que iban a repatriar a españoles condenados.

En todo caso, puede concluirse que si un español es detenido en un país extranjero, tardará como mínimo 2 años —si todo va bien- en poder volver a España y durante ese tiempo vivirá con total seguridad en un centro de detención, en una cárcel para preventivos y en otra para penados, al margen de los traslados que pueda sufrir por cualesquiera otras circunstancias a cárceles dentro de ese país. Durante todo ese tiempo muy difícilmente recibirá visitas de sus familiares, aunque sí podrá hablar con ellos por teléfono en momentos puntuales.

Tras examinar todos los gráficos, podríamos establecer la siguiente perfilación criminal acerca de las personas españolas que cometen delitos

${ }^{38}$ Resulta llamativo en Perú, aunque no es el único país en el que ocurre, el problema de la imposibilidad de sr trasladados a España por la obligación de satisfacer previamente conceptos «indemnizatorios» (ver Defensor del Pueblo, Estudio sobre la situación, op. cit., p. 19).

39 En el caso del programa Restauravidas han sido 4 personas. El certificado de libertad expedido por Perú va firmado por el director del establecimiento penitenciario y recoge la identidad del penado, la fecha de ingreso en el sistema penitenciario, la fecha de egreso de este y los datos de la causa penal, concediendo la libertad por «pena cumplida», conforme al art. 20 del Decreto Legislativo 654 del Código de Ejecución Penal.

40 Dicha repatriación se hace en observancia de la orden de expulsión por cumplimiento de condena con impedimento de ingreso por 15 años que realiza el Ministerio del Interior, en este caso, de Perú; pero necesita de la aprobación del Ministerio de Asuntos Exteriores de España, toda vez que éste de aprobar su repatriación sin coste para la persona en un avión. Son determinantes en estos casos, las peticiones que realizan los cónsules a dicho ministerio, certificando la situación de insolvencia de los liberados, la necesidad de cumplir con las normas migratorias en materia de permanencia irregular y la necesidad de trasladar a estar personas por motivos humanitarios y de insolvencia para hacer frente a su propio traslado. 
contra la salud pública ejerciendo de «mulas»: varón, de 50 años de edad, con formación básica, en situación de desempleo desde hace años, con una situación económica muy difícil (vivienda embargada y viviendo de las escasas pensiones de sus padres mayores), sin expectativas de futuro, sin antecedentes penales ni trayectoria delictiva de ninguna clase, utilizado como cebo para transportar clorhidrato de cocaína en una mochila, posiblemente detenido y encarcelado en Perú, con una sentencia condenatoria de conformidad de 6 años y 8 meses de prisión, más una multa económica que habrá de pagar si quiere ser trasladado y habiendo estado en cárceles de Perú por un tiempo de 3 años, sin haber recibido visitas de sus familiares, pues éstos no tienen medios para trasladarse, toda vez que el dinero que han podido reunir es para que haga frente a la multa derivada del delito.

\section{La experiencia en prisión en el extranjero}

La experiencia de estancia en prisión en el extranjero varía mucho en función del país de cumplimiento. Se atribuye a Fiodor Dostoyevski, quien pasó 5 años realizando trabajos forzados en un campo de Siberia ${ }^{41}$,la cita «el grado de civilización de una sociedad se mide por el trato a sus presos». No es lo mismo cumplir la pena privativa de libertad en determinados países de Europa, en cuanto a condiciones materiales y respeto a los derechos humanos, con unos estándares exigentes, que en cárceles donde no se exigen.

Todos los participantes en el programa «Restauravidas» que han sido trasladados desde cárceles de América Latina (independientemente del delito cometido) han sufrido una pena inhumana y un trato degradante. Esta manifestación tan rotunda viene respaldada, por un lado, por el concepto que tenemos en Europa sobre estos términos, y por otro, por los 22 relatos analizados y coincidentes entre sí $^{42}$.

El artículo 7 PIDCP dice: «Nadie será sometido a torturas ni a penas o tratos crueles, inhumanos o degradantes. En particular, nadie será sometido sin su libre consentimiento a experimentos médicos o científicos». Según el artículo 3 del Convenio Europeo para la protección de los derechos humanos y las libertades fundamentales: «Nadie podrá ser sometido a tortura ni a penas o tratos inhumanos o degradantes». La interpretación de lo que supone tortura y pena o trato inhumano o degradante la encontramos en numerosa jurisprudencia del Tribunal

${ }^{41}$ Cristina Roda Rivera, en https://lamenteesmaravillosa.com/9-frases-del-genio-fiodor-dostoyevski/ (última consulta 21 de mayo de 2021).

${ }_{42}$ Que vienen a confirmar lo que han trasmitido los numerosos documentales que existe sobre esta materia, como la ya referida serie "Encarcelados», de La Sexta. 
Europeo de Derechos Humanos (TEDH) ${ }^{43}$, que considera pena o trato inhumano o degradante del art. 3 en su vertiente material las siguientes situaciones $^{44}$ :

a) Golpes, palizas y trato vejatorio por parte de las autoridades.

b) Condiciones materiales de las celdas y de los espacios comunes: falta de espacio en las celdas - la medida de la celda no debe ser menor de 3 metros cuadrados-, - escasez de lugares para dormir, acceso limitado a la luz y al aire fresco, falta de privacidad en el uso de los sanitarios, presencia de ratas, cucarachas, ratones y hormigas. Esta problemática se da sobre todo en Rusia, Italia, Bulgaria, Hungría, Rumanía y Ucrania, que son los países más condenados por el TEDH ${ }^{45}$. La situación es tan alarmante ${ }^{46}$ que el Tribunal Europeo ya ha dictado siete sentencias piloto ${ }^{47}$ sobre el estado de las cárceles en estos países:

${ }^{43}$ El Tribunal Europeo de Derechos Humanos (TEDH), también denominado Corte Europea de Derechos Humanos ((ECHR por sus siglas en inglés) es un tribunal internacional que vela por la garantía de los derechos humanos y libertades fundamentales en toda Europa, excepto Bielorrusia, Kazajistán y la Ciudad del Vaticano. Está en la ciudad francesa de Estrasburgo. Vela por el cumplimiento de lo preceptuado en el Convenio El Convenio para la Protección de los Derechos Humanos y de las Libertades Fundamentales, más conocido como «Convenio Europeo de Derechos Humanos». Se abrió a la firma en Roma el 4 de noviembre de 1950 y entró en vigor el 3 de septiembre de 1953. El Convenio concretiza ciertos derechos y libertades contenidos en la Declaración Universal de Derechos Humanos y crea una jurisdicción internacional competente para condenar a los Estados que no respeten los compromisos asumidos con su ratificación o en sus protocolos adicionales. Un Protocolo al Convenio es un texto que añade uno o más derechos al texto inicial del Convenio o modifica algunas de sus disposiciones. Los Protocolos añaden derechos al Convenio que sólo son oponibles frente a los Estados que los hayan firmado y ratificado. La simple firma por un Estado a la que no siga su ratificación no es suficiente para obligar a ese Estado. Actualmente han sido adoptados 14 Protocolos adicionales. Su página web es https://www.echr.coe.int.

${ }_{44}$ S. Turturro Pérez De Los Cobos, «Las sentencias piloto del TEDH sobre los tratos inhumanos y degradantes en las cárceles europeas», Eunomía. Revista en Cultura de la Legalidad, n. 18, 2020, pp. 130-147: expone la dcotrina del TEDH en relación con las violaciones del art. 3 CEDH en las cárceles de algunos países europeos.

45 Aunque tampoco se libra Francia, que recientemente ha sido condenada por Sentencia de 5 de diciembre de 2019, Asunto J.M. c. Francia, por las condiciones degradantes que sufren algunos presos de sus cárceles.

${ }^{46}$ La Corte Europea constata que la mayoría de los demandantes disponían durante toda su reclusión de un espacio personal inferior a 3 metros cuadrados, es decir por debajo de la norma mínima requerida, y en cuanto a los que contaban con un espacio superior, las cárceles, en cualquier caso, "no ofrecían condiciones de detención decentes, ni suficientes, ni libertad de circulación y actividades fuera de las celdas".

47 El TEDH utiliza la técnica de las sentencias piloto a partir del caso Broniowski contra Polonia en el año 2004. Se considera una de las herramientas más innovadoras de las que ha desarrollado la Corte para abordar los casos repetitivos, también llamados «clónicos», derivados del mismo problema estructural subyacente en un Estado. Precisamente porque el Tribunal constata la existencia de un problema de esas características, suspende los procesos sobre casos idénticos y exige al Estado que adopte medidas generales. En consecuencia, en la técnica de las sentencias piloto la dimensión individual del recurso 

A. Caso Ananyev y otros contra Rusia, de 10 de enero de $2012^{48}$.
B. Caso Torreggiani y otros contra Italia, de 8 de enero de $2013^{49}$.
C. Caso Neshkov y otros contra Bulgaria, de 27 de enero de $2015^{50}$.
D. Caso Varga y otros contra Hungría, de 10 de marzo de $2015^{51}$.
E. Caso Rezmives y otros contra Rumania, de 25 de abril de $2017^{52}$.
F. Caso Sukachov contra Ucrania, de 30 de enero de $2020^{53}$.

c) Confinamiento en solitario de un ser humano con carácter indefinido, sin revisiones ni estimulación, aunque sea aislamiento relativo. Caso Ilascu contra Moldavia y Rusia, sentencia del TEDH de 8 de julio de $2004^{54}$.

d) Malos tratos por compañeros de celda. Caso Premininy contra Rusia, sentencia del TEDH de 10 de febrero de $2011^{55}$.

e) Abuso en el uso de la medida de contención con sujeción mecánica -inmovilización-. Caso Taly contra Estonia, sentencia de 13 de febrero de $2014^{56}$.

f) Traslados repetidos. Caso Bamouhammad contra Bélgica (43 traslados en 6 años), sentencia del TEDH de 17 de noviembre de $2015^{57}$.

g) Cacheos continuos. Caso Khider contra Francia, sentencia de 9 de julio de $2009^{58}$.

h) Registros corporales - por no usar guantes, o porque no se realiza por personas del mismo sexo, o en habitaciones sin intimidad o con vídeo vigilancia en baños-. Casos Valasinas contra Lituania, sentencia de 24 de julio de $2001^{59}$ y Riina contra Italia, sentencia de 13 de marzo de $2013^{60}$.

\footnotetext{
queda diluida, mientras que respecto al derecho subjetivo se evidencia la tendencia a objetivar las demandas. El procedimiento piloto está claramente regulado desde que, en marzo de 2011, la Corte modificó el art. 61 de su Reglamento, codificando el procedimiento preexistente para el dictado de este tipo de sentencias y estableciendo un claro marco regulatorio para las mismas. J. ABRISKETA URIARTE, «Las sentencias piloto: el tribunal europeo de derechos humanos, de juez a legislador», Revista Española de Derecho Internacional (REDI), vol. LXV, n. 1, 2013, p. 73.

48 Demanda $^{\circ} 42525 / 07$ y 60800/08.

49 Demanda ${ }^{\circ} 43517 / 09$.

50 Demanda $n^{\circ} 36925 / 10$.

51 Demanda $^{\circ} 15707 / 10$ y $14097 / 12$.

52 Demanda $^{\circ}$ 61467/12, 39516/13, 48231/13, 68191/13.

53 Demanda ${ }^{\circ} 14057 / 17$.

54 Demanda ${ }^{\circ} 48787 / 99$.

55 Demanda n ${ }^{\circ} 44973 / 04$.

56 Demanda $n^{\circ}$ 66393/10.

57 Demanda $^{\circ}$ 47687/13.

58 Demanda no 39364/05.

59 Demanda ${ }^{\circ}$ 44558/98.

60 Demanda no 43575/09.
} 
i) Tratamiento médico inadecuado para los enfermos mentales, toda vez que deberían estar en centros especiales y no en cárceles. Sentencia piloto para Bélgica a través del caso W.D. contra Bélgica, de 6 de diciembre de $2016^{61}$.

j) No realizar actividades suficientes fuera de las celdas, lo que se traduce en falta de tratamiento. J.M.B y otros contra Francia, sentencia de 30 de enero de $2020^{62}$.

En este caso, se hace necesario analizar de manera sucinta la situación de España respecto a la observancia del cumplimiento de los derechos humanos, para a continuación compararla con los países de procedencia de los participantes en el programa "Restauravidas», para entender que cuando son trasladados a las cárceles en España, «sienten que han dejado el infierno atrás» ${ }^{63}$.

España cuenta actualmente con 181 pronunciamientos de la Corte Europea de Derechos Humanos ${ }^{64}: 124$ sentencias condenatorias en las que hay violación de al menos uno de los artículos del convenio europeo de derechos humanos, 50 absoluciones, 3 conformidades o acuerdos amistosos y 4 pronunciamientos diferentes. No existen sentencias piloto, ni cuasi piloto para España. Como se desprende de las estadísticas de la propia Corte Europea, la ciudadanía de nuestro país es de las que menos recurre a este tribunal. Esto se debe, en una pequeña parte, a la fecha de ratificación del convenio, en 1979, a pesar de que éste se aprobó en el año 1950. De ahí —entre otras cuestiones ${ }^{65}$ - que nuestras cifras de litigio frente a esta instancia europea sean menores que las de nuestros países vecinos. El resto de causas por las que se recurre tan poco ante el TEDH en el ámbito de la privación de libertad, y en concreto, en el ámbito de ejecución de la misma, son las siguientes: al hartazgo de los presos en el $86 \%$ de los casos; a la desconfianza de los presos en las instituciones judiciales europeas en un 15\%; al desconocimiento del funcionamiento del TEDH en un $96 \%$; a la creencia de que hay que tener elevados recursos económicos (porque no existe justicia gratuita) en un 94\%; a la nula formación de los abogados en materia de TEDH en un $79 \%$ y, por último, a la nula información jurídica que hay en las prisiones sobre este tribunal en un $99 \%{ }^{66}$.

61 Demanda $n^{\circ} 73548 / 13$.

62 Demanda $n^{\circ} 9671 / 15$.

63 Frase literal que citan el 100\% de los españoles trasladados desde cárceles de centro América y Sudamérica.

64 Datos de las estadísticas de la ECHR del año 2020, publicadas en su web https:// www.echr.coe.int/Pages/home.aspx?p=reports\&c=(consultado el 30.6.2021).

65 Ver E. Pascual Rodríguez, "Análisis comparado de sistemas penitenciarios europeos a la luz de la jurisprudencia del Tribunal Europeo de Derechos Humanos», Cuadernos digitales de Formación, n ${ }^{\circ}$ 2, Consejo General del Poder Judicial, 2016.

66 Datos obtenidos a través del Proyecto financiado por la Unión Europea Prison Litigation Network. JUST/2013/ACTION GRANTS que finalizó en el año 2016, cuyo objetivo 
Desde que entró en vigor el Protocolo número 11 al Convenio Para la Protección de los Derechos Humanos y de las Libertades Fundamentales relativo a la reestructuración del mecanismo de control establecido por el Convenio (Estrasburgo, 11 de mayo de 1994) BOE $\mathrm{n}^{\circ} 152$ de 26 de junio de 1998 aumentó significativamente el número de demandas registradas contra España, que en su mayoría han sido declaradas inadmisibles. El derecho a un proceso equitativo recogido en el art. 6.1 del convenio es el derecho que ha concentrado en los últimos años la mayor parte de las sentencias en las que el tribunal ha apreciado una violación del convenio por España - pero dicha vulneración queda fuera del interés de este artículo sobre la privación de libertad-.

En el ámbito del artículo 3 (prohibición de tortura y pena o trato inhumano o degradante -incluyendo la detención, la prisión provisional y la ejecución de la pena privativa de libertad-) las sentencias por las que Tribunal Europeo de Derechos Humanos ha condenado a España son las de la siguiente tabla ${ }^{67}$ :

\begin{tabular}{|c|c|c|}
\hline Asunto contra españa & Año Sentencia & $\begin{array}{c}\text { Condena por violación del } \\
\text { artículo } 3 \text { del convenio }\end{array}$ \\
\hline Martínez Sala y otros ${ }^{68}$ & 2004 & Vertiente procesal \\
\hline Beristain Ukar ${ }^{69}$ & 2005 & Vertiente procesal \\
\hline Iribarren Pinillos ${ }^{70}$ & 2009 & Vertiente material $^{71}$ \\
\hline San Argimiro Isasa ${ }^{72}$ & 2010 & Vertiente procesal \\
\hline Otamendi Egiguren $^{73}$ & 2012 & Vertiente procesal \\
\hline
\end{tabular}

fue comparar la jurisprudencia del TEDH en materia de privación de libertad en 14 países de la Unión Europea. En dicho proyecto se realizaron multitud de entrevistas a abogados, personas presas, jueces y fiscales de vigilancia penitenciaria y al Mecanismo de Prevención de la Tortura en España.

67 Ver también https://www.abogacia.es/wp-content/uploads/2016/12/Informe_Espana-ante-la-tortura-y-los-malos-tratos.pdf (consultado el 30.6.2021).

68 Demanda n ${ }^{\circ} 58438 / 00$.

69 Demanda no 40351/05.

70 Demanda ${ }^{\circ} 36777 / 03$.

71 También constatando la existencia de torturas está el Caso Mari Cruz Atxabal Puertas c. España, comunicación 1945/2010, Dictamen aprobado por el Comité de Derechos Humanos del PIDCP en su $107^{\circ}$ periodo de sesiones. Puede encontrarse una referencia en F. EtXeberRia et Al., Proyecto de investigación de la tortura y malos tratos en el País Vasco entre 1960-2014. Instituto Vasco de Criminología. Secretaría General de Derechos Humanos, Convivencia y Cooperación del Gobierno Vasco. Diciembre 2017, p. 86.

${ }_{72}$ Demanda $^{\circ} 2507 / 07$.

73 Demanda ${ }^{\circ} 47303 / 08$. 


\begin{tabular}{|l|c|c|}
\hline \multicolumn{1}{|c|}{ Asunto contra españa } & Año Sentencia & $\begin{array}{c}\text { Condena por violación del } \\
\text { artículo 3 del convenio }\end{array}$ \\
\hline BS $^{74}$ & 2012 & Vertiente procesal \\
\hline $\begin{array}{l}\text { Etxebarria Caballero y } \\
\text { Ataun Rojo }\end{array}$ & 2014 & Vertiente procesal \\
\hline Arratibel Garciandia $^{76}$ & 2015 & Vertiente procesal $^{\text {Bertiente procesal }}$ \\
\hline Beortegui Martínez $^{77}$ & 2016 & Vertiente material \\
\hline $\begin{array}{l}\text { Portu Juanenea y } \\
\text { Sarasola Yarzabal }\end{array}$ & 2018 & Vertiente procesal \\
\hline López Martínez $^{79}$ & 2021 & Vertienter \\
\hline
\end{tabular}

Ninguna de estas sentencias lo son por hechos cometidos dentro de las prisiones españolas. Todas son por hechos producidos bien en el marco de manifestaciones o concentraciones donde ha habido cargas policiales, o bien en el marco del régimen de la detención incomunicada en los calabozos. Es decir, que todas tienen en común que los hechos no investigados han sido cometidos por las fuerzas y cuerpos de seguridad del Estado, por supuesto con la complicidad de médicos forenses que no han investigado la etiología de las lesiones y de los jueces que no han querido investigar las denuncias.

España incurre de manera sistemática en una falta de investigación efectiva tendente a determinar si ha habido o no esos malos tratos alegados por los demandantes durante el periodo de duración de la detención, normalmente en la detención incomunicada y prolongada. No se examina con rigor, ni profundidad por parte del Estado Español la existencia de dicho trato inhumano.

Sin embargo, no hay sentencias condenando a España por vulneración del artículo 3 en la vertiente de trato inhumano o pena degradante en el ámbito penitenciario por las circunstancias antes recogidas. No significa que no se produzcan dichas violaciones del convenio ${ }^{80}$, solo significa que no llegan a pedir el amparo de la Corte Europea. Aunque también es cierto que podemos concluir que España se encuentra, en cuanto a

74 Demanda ${ }^{\circ}$ 47159/08.

75 Demandas n $^{\circ} 74016 / 12$ y n $^{\circ} 3344 / 13$.

76 Demanda $^{\circ}$ 58488/13.

77 Demanda $\mathrm{n}^{\circ} 36286 / 14$.

78 Demanda n ${ }^{\circ} 1653 / 13$.

79 Demanda $^{\circ} 32891 / 16$.

80 Informe CPT 2017 https://rm.coe.int/pdf/168076696c (consultado el 30.6.2021). 
condiciones materiales de las cárceles se refiere, entre los mejores países de la Unión Europea ${ }^{81}$.

Conforme a los estándares europeos podemos concluir que en las cárceles latinoamericanas hay una violación sistemática de los derechos humanos, conforme al art. 3 del Convenio Europeo de Derechos Humanos en cuanto a pena inhumana o degradante. Y llegamos a estas aseveraciones en cuanto a las condiciones que narran las personas que allí han estado ${ }^{82}$ :

a) Golpes, palizas y trato vejatorio por parte de las autoridades y otros presos:

"Las sanciones alli son humillantes. Consistían en pasear desnudo por el patio mientras recibías golpes de quien quisiese darte». Preso en República Dominicana.

«En Perú a los españoles nos tienen marginados. Nos desprecian totalmente y para ellos somos unos ladrones y escoria». Preso en Perú. "He aprendido que hay personas peores de lo que te imaginas".

b) Condiciones materiales de las celdas y de los espacios comunes:

«Estábamos 400 presos en una sala con dos agujeros para las heces. Normalizas la inhumanidad. Sientes hambre y sed todo el rato. Pasé mucho miedo, todos los días había agresiones». Preso en República Dominicana.

«Habia mantas de cucarachas. Teníamos que dormir con papel higiénico en los oídos para que no nos entrasen las cucarachas». Presa en Perú.

«Teníamos un cubo donde hacer las necesidades delante del resto». Preso en Perú.

"Tienes que pagar tu causa, esto significa que tienes que costearte tu trozo de suelo para dormir, tu colchón, tu comida y tus cosas. Hasta que recibi el dinero del consulado tuve que dormir de pie varias semanas, me sujetaban con unas correas a una columna para no caerme». Preso en Brasil.

81 Parece que ha tenido éxito la expresión de que «España está entre los ocho países con las mejores cárceles de toda la Unión Europea» como en Cadena SER de 5 de diciembre de 2017 (https://cadenaser.com/programa/2017/12/05/hoy_por_ hoy/1512494200_844641.html) o en El Confidencial Digital de 24 de agosto de 2013 (https://www.elconfidencialdigital.com/articulo/te_lo_aclaro/Viven-bien-presos-carcelesespanolas/20130824010000069924.html), con más precisión en La Vanguardia de 7 de abril de 2020 (https://www.lavanguardia.com/politica/20200407/48374145605/las-carceles-espanolas-estan-entre-las-menos-masificadas-de-europa.html), consultados ambos el 30.6.2021. Es cierto que en los informes anuales SPACE I (ver AEBI Y TIAGO, "Space I - 2020», op. cit., pp. 4-6) se realizan unos rankings por indicadores, en los cuáles España está en la horquilla alta o muy alta en variables como ratio de personas encarceladas por 100.000 habitantes, de mujeres encarceladas, de extranjeros, de mayores de 50 y presos por funcionario, pero en bajo o muy bajo en presos preventivos o densidad poblacional. Una comparación con países europeos puede encontrarse en PASCUAL RoDRíGUEZ, "Análisis comparado de sistemas", op. cit.

82 En cárceles de Brasil, Perú, Panamá, Venezuela, República Dominicana y Colombia. 
"He estado 6 años y 8 meses durmiendo en una colchoneta en un pasillo. Junto a mí había un colchón en el que dormían dos presos que mantenían relaciones sexuales todas las noches sin excepción antes de dormirse». Preso en Perú.

"Dormía en el suelo, me daban dos trozos de pan y un puñado de arroz». Preso en Perú.

"En la cárcel de La Joya un espacio de cemento del tamaño de una cama costaba 1500 dólares al mes. Había muchísimo dinero en efectivo. Los presos son los que decoran la cárcel y la mejoran. Si no tienes dinero, te dan lo mínimo, un arroz asqueroso una vez al día. Moría muchísima gente en prisión. Había reyertas diarias. A mí me partieron la nariz una vez y me apuñalaron en dos ocasiones. Suerte que mi madre pudo mandarme dinero para poder pagar las curas y los medicamentos». Preso en Panamá.

c) Malos tratos por compañeros de celda:

«En Tocorón, Venezuela, existen castas: carro sucio, sujetaos, población, luceros y guerreros. Quienes vigilan en Venezuela las cárceles son los presos, no los funcionarios, así que son ellos los que aplican las sanciones y los malos tratos». Presa en Venezuela.

"La corrupción es institucional. Si tienes dinero pues conseguir de todo. Si no tienes, prepárate para adentrarte en el infierno». Presa en Venezuela.

d) Registros corporales:

"Mensualmente hacían un cacheo con desnudo integral delante de toda la prisión. Ha sido la mayor vejación a la que me he visto sometido en mi vida. Un día me enfrenté a un guardia por este motivo y del golpe que me dio me arrancó las dentaduras postizas que llevaba y que ya nunca logré recuperar». Preso en Brasil.

e) Tratamiento médico inadecuado para los enfermos mentales:

"Allí no reciben tratamiento médico nadie, así que los enfermos mentales menos. No existe esa clasificación. Al médico le llaman "el tópico" y apenas tiene medios, ni remedios para tratar nada. Es mejor no enfermar, si no quieres morir. Yo he visto morir a varios españoles y ha sido algo muy duro. Sobre todo, al pensar que era por cosas que en España se curan fácilmente». Presa en Perú.

"He visto morir a 7 españoles en 6 años por no recibir tratamiento médico». Preso en Perú.

"Muchos españoles de edad avanzada acabamos con problemas en las caderas por dormir tantos años en el suelo. Nunca logramos que nos diesen nada para el dolor». Preso en Brasil.

Como vemos se dan todas las vulneraciones posibles del art. 3 del Convenio Europeo de Derechos Humanos, tanto en la vertiente material como en la procesal, exceptuando la medida de confinamiento, el uso inadecuado de spray y los traslados continuos.

Ocurre, en definitiva, el proceso que se denomina victimización terciaria, en referencia al conjunto de costes adicionales a la penalización 
que soporta la persona penada o su familia o entorno ${ }^{83}$. La injusticia vivida en la detención, en el proceso penal; la indefensión, el abuso, la desproporción de la pena y la miríada de vejaciones, malos tratos y torturas sufridas durante su encarcelamiento colapsan al individuo en torno a esa única realidad.

\section{La aplicación de la justicia restaurativa a través del programa «Restauravidas»}

¿Puede la justicia restaurativa hacerse un hueco en la ejecución de la pena por delitos de tráfico de drogas? Sin duda, «la Justicia restaurativa es un enfoque que considera necesidades y roles» ${ }^{84}$, en primer lugar, de la víctima del delito. Lógicamente, la mediación penal, mediación autorvíctima $^{85}$, en cuanto encuentro ${ }^{86}$, necesita de una víctima concreta e individualizada para poder llevarse a cabo. En el caso de los delitos de peligro abstracto en relación con un bien jurídico supraindividual, como lo son los delitos contra la salud pública, se cuestiona la viabilidad de la mediación por la ausencia de una víctima concreta y un daño individual. Sin embargo, esta no es más que una de las herramientas de las que se nutre la justicia restaurativa, por lo que siempre se podrá recurrir a otros mecanismos donde encontrar los fines que ésta persigue, a saber: responsabilización del daño cometido, reparación económica y/o simbólica y pacificación social ${ }^{87}$.

De ahí que el programa «Restauravidas» naciese con la vocación, por un lado, de dar respuesta a las necesidades que determinan reforzar la acogida de estas personas trasladadas desde el extranjero para continuar

83 G. VARONA ET AL., Victimología: un acercamiento a sus conceptos fundamentales. UPV-EHU, 2015, p. 62; A. GARcíA-PABlos DE Molina, «El redescubrimiento de la víctima: victimización secundaria y programas de reparación del daño. La denominada "victimización terciaria” (el penado como víctima del sistema legal)», en La victimología, CDJ, Madrid, 1993, p. 313. Específicamente sobre victimización terciaria penitenciaria en España, véase X. FERrEIRo BAAMONDE, "Os danos que o sistema penal causa ás persoas sometidas a proceso: a victimización terciaria», Anuario da Facultade de Dereito da Universidade da Coruña, n. 6, 2002, pp. 365 y ss.

84 ZEHR, op. cit., p. 18.

85 En este sentido, en esto como fórmulas similares, también otros mecanismos restaurativos como conferencias y círculos.

${ }^{86}$ Sobre estas diferentes concepciones de justicia restaurativa puede verse UNODC Manual de Programas de justicia restaurativa. Nueva York. 2006, p. 104. Así, la concepción reparadora y transformadora, estaría más abierta a fórmulas restaurativas sin necesidad de un encuentro con una víctima concreta.

87 "...la justicia restaurativa está construida sobre tres elementos sencillos o pilares: los daños y las necesidades asociadas a ellos (primeramente de las víctimas, pero también de las comunidades y los ofensores); las obligaciones que conlleva este daño, así como las que le dieron origen (obligaciones de los ofensores y también de las comunidades); y la participación de todas aquellas personas que tengan un interés legítimo en la ofensa y su reparación (víctimas, ofensores y otros miembros de la comunidad)»(ZEHR, op. cit., p. 31). 
cumpliendo la condena en España y por otro, de estudiar la viabilidad de la justicia restaurativa en este tipo de delitos.

El desarrollo del programa que se lleva a cabo en la prisión de Madrid V (que es el primer destino al que llegan las personas trasladadas desde el aeropuerto extranjero) comienza con la derivación al mismo por parte de la Subdirección de Tratamiento. A partir de ahí se realizan entrevistas individuales de las facilitadoras con las personas trasladadas, con la finalidad de informar sobre el programa, su duración (va a depender lo que se tarde en trabajar los 6 bloques), los requisitos de acceso (voluntario, confidencial, gratuito), el papel de los facilitadores y la finalidad de este ${ }^{88}$. Si aceptan participar, comienza el trabajo en círculos restaurativos, en el que hay orientación jurídica y apoyo psicológico hasta que éste finaliza. Los bloques de trabajo en los que se estructuran las sesiones de los círculos son los siguientes:

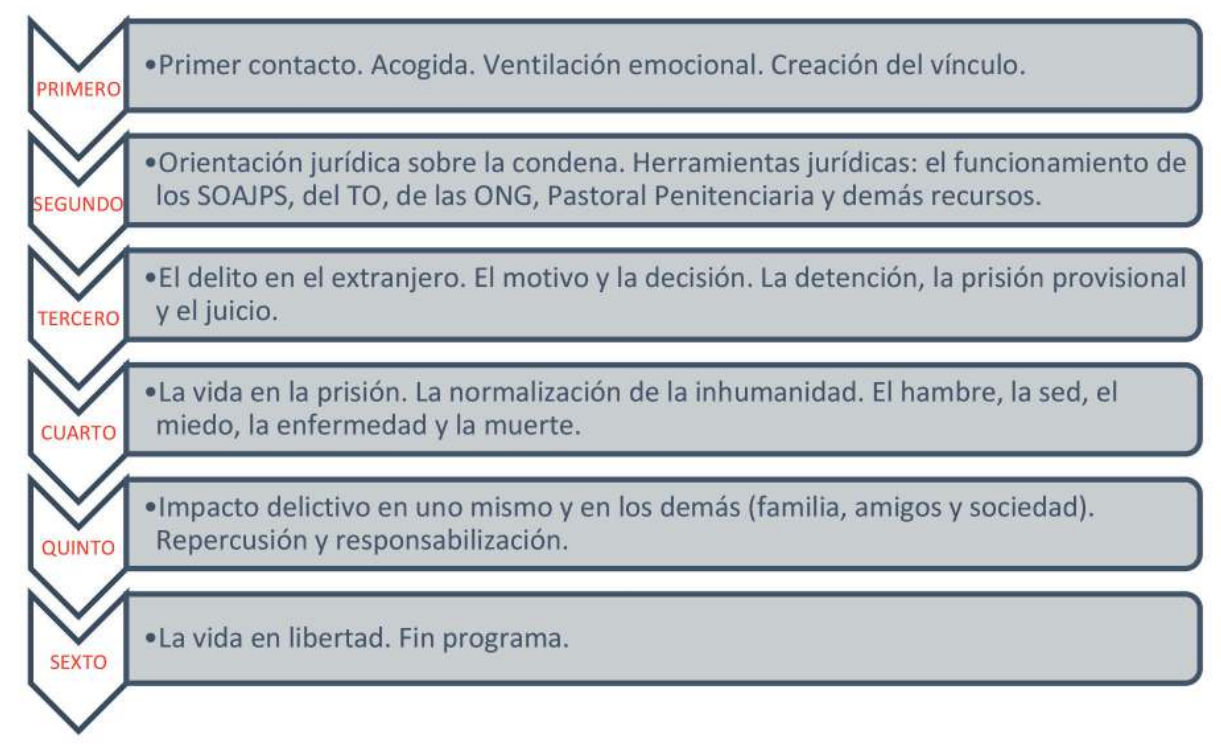

Con el programa se ha detectado que hay una serie de necesidades que requieren reforzar la acogida:

${ }^{88}$ Los objetivos del programa son: $1^{\circ}$ ) acompañar a las personas a entender e integrar la vivencia de la condena en el extranjero; $2^{\circ}$ ) dar una oportunidad segura de tener un diálogo significativo que les ayude a abordar las consecuencias emocionales y de otro tipo; $3^{\circ}$ ) aumentar la percepción de control de su vida en prisión a través del manejo de información relevante para su vida penitenciaria; $4^{\circ}$ ) ayudarles a adaptarse a la vida de vuelta a su país a nivel personal y familiar y $5^{\circ}$ ) asesorarles y facilitarles la salida en libertad en diversos ámbitos de funcionamiento. 
a) Asistenciales (necesidad de ropa, de recuperación de hijos, de recursos sociales para avales de permisos, del subsidio de excarcelación)

b) Legales (necesitan saber a qué juzgado deben dirigirse si quieren recurrir las decisiones de la administración penitenciaria, conocer cómo funciona aquí el sistema penitenciario, saber si les adaptan aquí su condena, qué tipo de servicios jurídicos gratuitos existen, etc.)

c) De comunicación (con sus familiares, abogados en el extranjero, sus amigos y con los técnicos de la administración penitenciaria).

d) Médicas (si deben hacer cuarentena, gafas, dentaduras, especialidades médicas, salud mental).

e) Psicológicas (manejo del estrés postraumático, el miedo al futuro, abordar el tema de la familia, qué contar y qué no contar, compartir vivencias etc.).

Junto a estas, se hace un pequeño hueco la justicia restaurativa, pero muy pequeño, toda vez que estas necesidades pueden venir proporcionadas por otros medios u otras herramientas. El objetivo, humildemente restaurativo, era buscar la responsabilización individual en relación con el delito cometido y su gravedad desde la comprensión de los daños generados por el abuso de las drogas.

Sin embargo, es de tal magnitud la victimización terciaria que han sufrido que les imposibilita asumir, al menos en la fase inicial, que hayan podido generar algún tipo de daño a la sociedad; quien lo reconoce en este primer momento, considera que ha sido mínimo a la sociedad y máximo a sus familias, por lo que el enfoque restaurativo del programa encuentra su razón de ser en una mediación familiar para la recuperación y/o normalización de las relaciones familiares, toda vez que hay relaciones que se han ido enfriando, enquistando o muriendo. Su participación en el programa les sirve para ver de qué manera pueden volver a recuperar el vínculo. La familia sigue siendo el pilar fundamental de muchas de estas personas. Aquello a lo que se han aferrado para no caer en el olvido y dejarse morir, de ahí la necesidad de recuperar las relaciones familiares con hijos, padres, abuelos, hermanos, etc.

La labor que realizan los Consulados de España en el extranjero (a veces calificada como inexistente y en la mayor parte de los casos, muy acertada y necesaria con el apoyo económico que prestan) es de vital importancia para los españoles condenados en el extranjero. Son el único hilo invisible que les acerca a su país. De ahí la necesidad de que los consulados conozcan el impacto de su trabajo en estas personas para que incrementen las visitas, sobre todo en las provincias (realizan más visitas en las capitales) y el apoyo, pues son faros de luz en la oscuridad para personas en situaciones de extrema necesidad. 
La labor de la Fundación $+34^{89}$ es determinante para los presos españoles en las cárceles de Latinoamérica, así como el trabajo de la Fundación Abogacía Española a la hora de impulsar los traslados y prestar apoyo legal en numerosos países.

El efecto de inocuización de la pena - de la prevención especial negativa- se cumple íntegramente, pero no habría sucedido lo mismo con el efecto de prevención general. Los propios condenados reconocen que la pena posible por el delito no les intimidó en ningún momento. Sin embargo, tras su paso por prisión y sabiendo como es, no contemplan esta opción delictiva jamás en sus vidas. Le pedimos a un preso que nos dijese qué le diría a una persona que esté planteándose hacer un viaje portando droga para salir de un apuro económico y nos dijo esto:

"El dinero que vas a ganar no justifica lo que vas a tener que soportar. Te van a hacer lo peor: humillaciones, golpes, vejaciones, vas a pasar hambre, sed, vas a sentir miedo de todo y de enfermar y en el camino se van a quedar muchas personas a las que quieres. No hay ninguna necesidad que justifique lo que vas a vivir».

¿Qué función cumple la continuación del cumplimiento de la pena en España? ¿Es razonable que España siga adherida a la opción del Convenio de Estrasburgo que impide adaptar la condena a la legislación española, al contrario de lo que ocurre en el marco de la UE? ¿El exceso de penalización, la victimización terciaria, el sufrimiento y los malos tratos y vejaciones sufridas no han de tener ninguna repercusión sobre el merecimiento y la necesidad de la ejecución del resto de la pena en España ${ }^{90}$ ? Siendo conscientes de la importancia de cuidar los vínculos y relaciones internacionales concernidos, tenemos la firme convicción de que estas personas serían acreedoras al indulto de una parte relevante de su condena o al menos deberían poder acceder con carácter general a la clasificación inicial en $3^{\circ}$ grado, o al menos al art. 100.2 RP, y al adelantamiento de la libertad condicional a las $2 / 3$ partes en todo caso. Necesitan con premura recuperarse física y mentalmente, retomar las relaciones con su familia e ir preparando su vida en libertad. Su peligrosidad criminal es nula y la experiencia de cárcel que han sufrido es de tal intensidad que

${ }^{89}$ Fundación que trabaja para asesorar a las familias, y por la calidad de vida y reinserción de los presos españoles en el extranjero, http://www.fundacionmas34.org/ (última consulta 30 de mayo de 2021).

${ }_{90}$ Simplemente téngase en cuenta, por poner una situación particular, por ejemplo que en Venezuela la condena tiene aparejadas redenciones, pero como no se aplican a la liquidación de condena en Venezuela, no constan documentalmente, no tienen repercusión en España, lo que da lugar a que la pena a cumplir en España en estos casos supere la que legalmente corresponde. La Sala de lo Penal de la Audiencia Nacional debería requerir de oficio a Venezuela que el Tribunal Sentenciador documente la liquidación de condena con las redenciones aplicadas. 
un país como España no debería permitir que sigan sufriendo una pena privativa de libertad una vez que han llegado a su país.

La última conclusión es que no queda espacio, en personas que han sufrido lo indescriptible, para la responsabilización por el daño cometido a los demás con su delito; no es posible, en general, el trabajo restaurativo, la encarnación del sufrimiento de las víctimas potenciales, la empatía con el daño social de la droga, en personas ya llenas de dolor.

\section{Bibliografía}

Aguilera ReiJa, M., «Mujeres en prisiones españolas», La cárcel del siglo XXI: desmontando mitos y recreando alternativas, Año 61, n 973, 2011, pp. 44-48.

Calle Calderón, A.L., El estado de necesidad y el caso de las drogas en la doctrina del Tribunal Supremo. Una crítica desde la perspectiva latinoamericana. Tesis doctoral. Universidad d Girona. 2015, https://www. tdx.cat/handle/10803/327318\#page $=1$.

Cid Moliné, J., "El futuro de la prisión en España». Revista Española de Investigación Criminológica, art. 1, n. 18, 2020 pp. 1-32. https://doi. org/10.46381/reic.v18i0.285.

EtXebarria Zarrabeitia, X., «Propuesta de interpretación del segundo párrafo del art. 368 del Código penal», La Ley Penal, n 85, Sección Legislación aplicada a la práctica, septiembre 2011, pp. 3-11.

EtXeberria, F., Et AL., Proyecto de investigación de la tortura y malos tratos en el País Vasco entre 1960-2014. Instituto Vasco de Criminología. Secretaría General de Derechos Humanos, Convivencia y Cooperación del Gobierno Vasco. Diciembre 2017.

FERreo BAAmonde, X., «Os danos que o sistema penal causa ás persoas sometidas a proceso: a victimización terciaria». Anuario da Facultade de Dereito da Universidade da Coruña, n. 6, 2002, pp. 359-372.

García-Pablos De Molina, A., "El redescubrimiento de la víctima: victimización secundaria y programas de reparación del daño. La denominada "victimización terciaria» (el penado como víctima del sistema legal)», en La victimología, CDJ, Madrid, 1993.

LAI, G., «Drogas, crimen y castigo. Proporcionalidad de las penas por delitos de drogas» en la Serie reforma legislativa en materia de drogas, $\mathrm{n}^{\mathrm{o}}$ 20, Transnational Institute, junio 2012, pp. 1-15. https://www.unodc. org/documents/congress/background-information/NGO/IDPC/IDPCTNI-briefing-paper_Drogas-crimen-y-castigo.pdf.

Martínez Escamilla, M., "Pobreza, estado de necesidad y prevención general: los correos de la cocaína y el tribunal supremo español», Derecho Penal Contemporáneo: Revista Internacional, no 12, 2005, pp. 5-52. 
Molina Blázouez, C., «Necesidad y derecho penal: el hurto famélico, los «correos de la coca» y la ocupación pacífica de inmuebles», en BENITO SÁNCHEZ y Gómez Lanz, Sistema penal y exclusión social, Cizur Menor, Aranzadi, 2020, pp. 109-138.

Monteserín, E., Los correos de la cocaína. Tesis doctoral. Universidad Complutense de Madrid. 1995.

Pascual Rodríguez, E., «Análisis comparado de sistemas penitenciarios europeos a la luz de la jurisprudencia del Tribunal Europeo de Derechos Humanos», Cuadernos digitales de Formación, $\mathrm{n}^{\circ}$ 2, Consejo General del Poder Judicial, 2016.

Turturro Pérez De Los Cobos, S., «Las sentencias piloto del TEDH sobre los tratos inhumanos y degradantes en las cárceles europeas», Eunomía. Revista en Cultura de la Legalidad, n. 18, 2020, pp. 130-147. https://doi.org/10.20318/eunomia.2020.5267.

Varona Martínez, G. ET AL., Victimología: un acercamiento a sus conceptos fundamentales, OCW. Donostia-San Sebastián, 2015.

ZEHR, H., El pequeño libro de la justicia restaurativa, Good books, 2005.

\section{Documentos oficiales e informes}

Aebi, M.F, Tiago, M.M.. SPACE I - 2020 - Council of Europe Annual Penal Statistics: Prison populations. Strasbourg: Council of Europe. 2021. https://wp.unil.ch/space/space-i/annual-reports.

Asociación Pro Derechos Humanos de Andalucía (APDHA), Informe sobre la situación de las mujeres presas, Tratamiento y derechos de las mujeres privadas de libertad en los centros penitenciarios de España y Andalucía, 2020.

Defensor Del Pueblo Andaluz, Mujeres privadas de libertad en centros penitenciarios de Andalucía, Sevilla, 2006.

Defensor Del Pueblo Andaluz, Informe anual 2018, Mecanismo Nacional de Prevención, Supervisión de lugares de privación de libertad en España, de acuerdo con el Protocolo facultativo a la Convención de las Naciones Unidas contra la tortura y otros tratos o penas crueles, inhumanos o degradantes (OPCAT).

Defensor Del Pueblo. Estudio sobre la situación de los presos españoles en el extranjero. Madrid. 2015.

Secretaría General De Instituciones Penitenciarias, La situación de la mujer privada de libertad en la Institución Penitenciaria, 2021.

UNODC, World Drug Report 2020. https://wdr.unodc.org/wdr2020/index. html. 


\section{Sentencias del Tribunal Europeo de Derechos Humanos}

1. Caso Ananyev y otros contra Rusia, sentencia de 10 de enero de 2012. Demanda n ${ }^{\circ}$ 42525/07 y 60800/08.

2. Caso Torreggiani y otros contra Italia, sentencia de 8 de enero de 2013. Demanda $\mathrm{n}^{\circ} 43517 / 09$.

3. Caso Neshkov y otros contra Bulgaria, sentencia de 27 de enero de 2015. Demanda $\mathrm{n}^{\circ}$ 36925/10.

4. Caso Varga y otros contra Hungría, sentencia de 10 de marzo de 2015. Demandas n ${ }^{\circ} 15707 / 10$ y 14097/12.

5. Caso Rezmives y otros contra Rumania, sentencia de 25 de abril de 2017. Demandas n ${ }^{\circ}$ 61467/12, 39516/13, 48231/13, 68191/13.

6. Caso Sukachov contra Ucrania, sentencia de 30 de enero de 2020. Demanda $\mathrm{n}^{\circ}$ 14057/17.

7. Caso Ilascu contra Moldavia y Rusia, sentencia de 8 de julio de 2004. Demanda $\mathrm{n}^{\circ}$ 48787/99.

8. Caso Premininy contra Rusia, sentencia de 10 de febrero de 2011. Demanda $\mathrm{n}^{\circ}$ 44973/04.

9. Caso Taly contra Estonia, sentencia de 13 de febrero de 2014. Demanda ${ }^{\circ}$ 66393/10.

10. Caso Bamouhammad contra Bélgica, sentencia de 17 de noviembre de 2015. Demanda n ${ }^{\circ} 47687 / 13$.

11. Caso Khider contra Francia, sentencia de 9 de julio de 2009. Demanda $n^{\circ} 39364 / 05$.

12. Caso Valasinas contra Lituania, sentencia de 24 de julio de 2001. Demanda $\mathrm{n}^{\circ}$ 44558/98.

13. Caso Riina contra Italia, sentencia de 13 de marzo de 2013. Demanda $n^{\circ} 43575 / 09$.

14. Caso W.D. contra Bélgica, sentencia de 6 de diciembre de 2016. Demanda $\mathrm{n}^{\circ} 73548 / 13$.

15. Caso J.M.B. y otros contra Francia, sentencia de 30 de enero de 2020. Demanda n ${ }^{\circ} 9671 / 15$.

16. Caso Martínez Sala y otros contra España, sentencia de 2 de noviembre de 2004. Demanda n ${ }^{\circ}$ 58438/00.

17. Caso Beristain Ukar contra España, sentencia de 8 de marzo de 2011. Demanda $\mathrm{n}^{\circ}$ 40351/05.

18. Caso Iribarren Pinillos contra España, sentencia de 8 de enero de 2009. Demanda n $36777 / 03$.

19. Caso San Argimiro Isasa contra España, sentencia de 28 de diciembre de 2010. Demanda ${ }^{\circ}$ 2507/07. 
20. Caso Otamendi Egiguren contra España, sentencia de 16 de octubre de 2012. Demanda ${ }^{\circ}$ 47303/08.

21. Caso BS contra España, sentencia de 24 de julio de 2012. Demanda $\mathrm{n}^{\circ} 47159 / 08$.

22. Caso Etxebarria Caballero y Ataun Rojo contra España, sentencia de 7 de octubre de 2014. Demandas n ${ }^{\circ} 74016 / 12$ y n $^{\circ} 3344 / 13$.

23. Caso Arratibel Garciandia contra España, sentencia de 5 de mayo de 2015. Demanda $\mathrm{n}^{\circ}$ 58488/13.

24. Caso Beortegui Martínez contra España, sentencia de 31 de mayo de 2016. Demanda n $36286 / 14$.

25. Caso Portu Juanenea y Sarasola Yarzabal contra España, sentencia de 13 de febrero de 2018. Demanda n ${ }^{\circ}$ 1653/13.

26. Caso López Martínez contra España, sentencia de 9 de marzo de 2021. Demanda ${ }^{\circ}$ 32891/16. 